Original scientific paper

UDK: 314.74(497.11)

DOI: $10.5937 / J R S 1802131 \mathrm{~L}$

Received: 15 July 2018 / Accepted: 6 August 2018

\title{
"Migration Crisis" and the Far Right Networks in Europe: A Case Study of Serbia
}

\author{
MARINA LAŽETIĆ* \\ The Fletcher School of Law and Diplomacy, Tufts University, US
}

\begin{abstract}
During the "migration crisis" Serbia has been a transit country. However, several thousands of migrants and refugees remained "stuck" in the Western Balkans after the closure of the Balkan Route, and issues related to their potential integration provided a platform for Serbian far right movements and parties to establish new and stronger relationships with their European counterparts. This changed the far right landscape in the Western Balkans and allowed anti-European narratives to strengthen. This paper identifies the "new far right" which is on the rise in Serbia, and its relationships with the larger network of European far right movements. Based on field interviews and social media content analysis, the paper draws a conclusion that if the EU fails to take a more active role in making integration an attractive option for the Western Balkan countries, the rise of far right movements in the region could present a serious security threat.
\end{abstract}

Keywords: migration, far right, rightwing, anti-immigrant, Serbia.

\section{Introduction}

In recent years Europe has experienced a massive influx of refugees from Middle Eastern and African countries, mainly due to civil wars and economic stagnation in these areas. The number of those heading for the European Union peaked in 2015, when Chancellor Angela Merkel decided to allow the entry of Syrian refugees who were "stuck" in Western Balkan countries. These developments have been accompanied by a steep rise in popularity of nationalist parties and far right movements across Europe, evident in their increased presence in public, social and political life. These far right actors threaten to change the social and political fabric of Europe as they enter deeper into the political scene and gain wider mass support, even in most progressive Western European countries such as Germany.

While the rise of the far right in the European Union has received significant attention in the media, as well as among scholars, countries of the Western Balkan have been somewhat neglected in this sense. The prospect of EU integration has been the driving force of transformation in the region, but recent developments concerning the social

*marinalazetic@gmail.com 
and political climate in the European Union have created increased tensions and doubts regarding integration. The "migration crisis" has exacerbated this sentiment, with a wide variety of far right actors now using the "failed integration" of migrants and refugees from the Middle East as proof that the European Union is actually a failed liberal experiment. As a result, far right actors have been uniting based on their ideology of national rebirth and return to national borders, strengthened by the anti-immigration platform. Even in transit countries such as Serbia, the issues related to the integration of several thousands of migrants who have remained "stuck" after the closure of the Balkan Route has provided a platform for far right movements and parties to establish new and stronger relationships.

As research on the far right is generally in its infancy, literature on the far right in the Western Balkans is still largely non-existent. Therefore, this paper reflects on literature focusing on the far right movements in Western as well as Eastern Europe, and applies them to the Serbian context. In the case study of Serbia, primary research data and material are presented to demonstrate how a cross-national network of far right movements is developed. This paper serves as a counterargument to the Serbian exceptionalism, by portraying how the "new far right", which is European as much as it is Serbian, carries increased risks to social and political stability beyond Serbia itself.

The first part of this paper presents theories and conceptual frameworks that provide reasons for recent re-emergence of the far right in Europe. As recent events show increasing similarities between the Russian and Eastern European far right and its Western counterparts, this paper incorporates a literature review focusing on Eastern and Western Europe, as well as a brief reflection on Russia's far right. The second part of the paper presents the case study of Serbia, where the "new far right" has been developing and connecting with the European movement over the past several years. The case study of Serbia portrays how anti-immigration sentiments serve as a mobilising tool that connects far right actors across ideological, structural, and even national borders.

In conclusion, this paper emphasises that overlooking the Serbian far right because of the assumed "Serbian exceptionalism" carries serious security threats that extend beyond the Serbian borders. While the Serbian far right has played a very important role during the conflict in the 1990s, and has maintained a strong grip on power ever since, treating Serbia as an outlier and marginalising the region has only made it more prone to radical influences. Research participants in this study referred to Serbia as "fertile ground" for national rebirth and a good starting point for the emergence of movements that will mobilise and organise masses across Europe. For this reason, many influential far right actors from Europe have found Serbia to be their place of "refuge", from which they continue to organise movements globally. 


\section{Methodology}

\section{Case Study - Why Serbia?}

In the past several decades, during which the far right in Serbia has been neglected by researchers in due to the assumed "Serbian exceptionalism", it has undergone important changes and "learned" from its European counterparts. Prompted by the most recent "migration crisis", several important European far right movements have made strong connections to Serbia and established offices therein. For example, Knights Templar International - the organisation created by the founder of Britain First, Jim Dowson tried to supply bullet-proof vests and radios to Serbian groups operating in Kosovo ${ }^{1}$. Meanwhile, the right-hand man of the influential Russian far right ideologue Alexander Dugin is often seen in Serbia with Dowson and the former British National Party leader Nick Griffin.

The lack of legal enforcement against the far right in Serbia provides a safe space for individuals such as Jim Dawson and Nick Griffin, who have been exiled from Europe due to their extremely nationalist stands. Should more European far right actors find refuge in Serbia, lack of awareness of their activities and the organisational and ideological shifts that are occurring on the far right scene could cause irreparable damage to the social and political systems of Serbia and create security concerns for the European Union itself.

\section{Participant Observations and Interviews}

I have identified four different groups of research participants, which also represent the main stakeholders: non-profit organisations, the government, the far right movements and parties, and the migrants themselves. I conducted interviews with the staff of 15 NGOs involved in the humanitarian response to the "migration crisis", government representatives working on refugee and migration policies, academics, journalists, and representatives of far right movements and parties in Belgrade. I carried out participant observation in the Krnjača, Obrenovac, Banja Koviljača, and Bogovođa asylum centres, and at the Refugee Aid Miksalište, a space where migrants gather, socialise and connect with the service-providing NGOs. This approach allowed for informal conversations with refugees and migrants that provided valuable insights into their experiences and the challenges they face in Serbia.

In order to understand whether Serbia experienced an increased activity of the far right movements as a result of the "migration crisis", I identified the most active far right movements in the country with the intent to conduct semi-structured, in-depth interviews with their representatives. At the time this research was conducted, most far right actors did not wish to voice their opinions on migration as the government position was still undefined and the migrant status unresolved. Out of ten active movements/parties that

1 BIRN 2017. 
I contacted in June 2017, seven agreed to participate in this study. It is important to mention that these are very different movements when it comes to structure, approach and ideology: the Serbian Radical Party is an official party, with representatives in the Serbian Parliament; Zavetnici is a movement that propagates the preservation of Serbian culture and ethnicity through return to nationalism and strong national policies; Srbska Akcija is a "volunteer movement" often associated with violent neo-fascist politics; while others are newly founded anti-immigration movements.

\begin{tabular}{|c|c|c|}
\hline Research participants and key informants & Men & Women \\
\hline $\begin{array}{l}\text { Number of individual research participants: } \mathrm{N}=47 \\
\text { Migrant participants were from: Afghanistan (11), Nigeria (2), Algeria (2), } \\
\text { Syria (1), South Sudan (1), Pakistan (2) and Iraq (4). } \\
\text { The migrants' education levels varied from some high school to a university } \\
\text { degree. } \\
\text { Serbian participants (24) were representatives of the government or local or } \\
\text { international non-profit organisations, and held a university degree. }\end{array}$ & 27 & 20 \\
\hline Age range & $20-58$ & $22-55$ \\
\hline $\begin{array}{l}\text { Number of key informants from non-profit organisations: N=24 } \\
\text { Main organisations of key informants: Catholic Relief Services; Čovekoljublje; } \\
\text { Initiative for Development and Cooperation; UNHCR Serbia; ADRA Serbia; } \\
\text { Grupa 484; Refugee Aid Miksalište; Danish Refugee Council; International } \\
\text { Organisation for Migration; ATINA Serbia; Belgrade Centre for Human } \\
\text { Rights; Commissariat for Refugees; Asylum Protection Centre APC / CZA }\end{array}$ & 6 & 18 \\
\hline $\begin{array}{l}\text { Number of key informants from far right movements/ parties/ organisations: } \\
\text { N=10 } \\
\text { Main movements/parties/organizations of key informants: Zavetnici, Srbska } \\
\text { Akcija, Srpska Radikalna Stranka, Anti-Imigracija, Pokret za slobodu i } \\
\text { nezavisnost, European Solidarity Front for Syria, Generacija Identiteta }\end{array}$ & 7 & 3 \\
\hline
\end{tabular}

Table 1: Breakout and overview of key informers and research participants Social Network Analysis

In this project, I adopted the methodology used for the study of terrorist networks and applied it to build knowledge and understanding of the far right network consisting of Serbian and European actors. Through interviews and informal conversations with the representatives of far right movements primarily based in Serbia, I gathered information about their own activities as well as those of the European far right movements which they consider to be their collaborators and supporters. Besides the European Solidarity Front for Syria, no European far right actors were interviewed as part of this study, but they were included in the social network analysis and graphs as they have been named by Serbian far right actors as collaborators or supporters. In addition, I carried out a comprehensive analysis of all the mentioned far right actors' social media, articles of association and missions, including website content, to confirm the existence of either open public support or strong collaboration between individual members of the movements represented in the network. The network consists of 21 actors whose ties are defined broadly - each tie between the organisations represents either public endorsement of initiatives, public support for one another, or collaboration on a project such as humanitarian action, public gathering, conference, etc. I used the UCINET programme to analyse the data, and Net 
Draw for data visualisation purposes. The social network analysis and data visualisation software allowed for a deeper understanding of "relational qualities" of the network (such as network centrality, different actors' capacity to serve as a bridge between different groups, to channel information, etc.) and the broader characteristics of the network that facilitated cooperation (internal cohesion, network stability, flexibility, density, etc.).

\section{Literature Review}

I conducted a comprehensive literature review through Tufts and Harvard University libraries. Databases available through these libraries were searched for keywords such as "rightwing extremism", "far right" and "extreme nationalism", with a specific focus on Europe. I included only articles that were published in peer-reviewed journals in the literature review relating to the far right. The same methodology was used to find additional material on migration and politics of migration in the European Union and the Western Balkans. Key search terms included "migration crisis", "Balkan route", "EU migration policy”, etc. I conducted the search in English as well as Serbian.

\section{Methodological Challenges and Limitations}

While in smaller Serbian towns the migrants experience more hostility from the host communities, as they are more visible and their presence is more felt, the headquarters of most NGOs working with the migrants as well as anti-immigration movements are located in Belgrade. Due to time and resource constrains, I conducted interviews only in Belgrade, while visits to the asylum centres and informal conversations held with migrants and aid workers mitigated some of the bias that might have resulted from the above.

The ever-changing nature of nationalist far right movements and parties presented another challenge. Many individuals that were identified through field research simultaneously belong to several movements and parties, while movements themselves often change names and disguise their mission by adopting a different organisational structure. Some do it because their activity or organisation has been deemed illegal or banned (although this doesn't happen often), while others evolve from a Facebook page into a movement and then into a registered organisation within a very short period of time. For this reason, it is possible that some of the actors that were included in the study have changed their names, or morphed into a different organisation during the time that passed between the field research and the appearance of this paper. 


\section{The European Far Right}

\section{Defining the Far Right}

Just as there is no one definition of terrorism, or one profile of a terrorist, there is also no one definition of far right extremism and its supporters. In linguistic terms, extreme is defined as something that is "stretched to the limit", and in the political sense this limit concerns political and social values of the society. Across different disciplines, however, the literature on far right extremism includes not only different definitions of the phenomenon itself, but also definitions of various actors: parties, movements, as well as sub-cultural milieux and cultural organisations, etc. Minkenberg defines far right radicalism as "a political ideology, the core element of which is a myth of a homogeneous nation, a romantic and populist ultranationalism which is directed against the concept of liberal and pluralistic democracy and its underlying principles of individualism and universalism". ${ }^{2}$ Therefore, the far right desires government by the people - but in terms of ethnocracy, where the idea of a nation is condensed into extreme ethnic, cultural, and religious homogeneity. These sentiments are strengthened and further reinforced by mass media and populist campaigns that seek to appeal to the dissatisfied segment of the population in particular. The far right ideology is particularly attractive to people who do not trust institutions and are looking for an answer to their personal and collective failures ${ }^{3}$. The literature refers to a variety of actors with this ideology as "extreme" or "radical" interchangeably. Throughout this paper, far right is used to refer to far right nationalist parties and organisations, new anti-immigrant movements, and neo-fascist organisations united around a nationalist ideology that support national rebirth and a mono-ethnic state.

While the reasons for support for the far right movements are not at the centre of this study, it is important to discern the key reasons for it in order to be able to understand their recent re-emergence and appeal. There are several theories that attempt to explain the support for the far right. Some of the most popular explanations include: sociopsychological, social background, and socio-structural.

Socio-psychological explanations focus on the appeal that the far right has had after the World War II, and they mainly focus on individual personality traits and value systems that make a person more likely to be supportive of and receptive to the far right ideology $y^{4}$. This category comprises theories about group conflicts, as well as classical theories of scapegoating and realistic group conflict theories ${ }^{5}$. Both of these theories speak about group conflict as the root cause of conflict between different ethnic groups. Scapegoating is considered to be driven by and based on emotions, while realistic group conflict

2 Minkenberg 2000.

3 Rydgren 2013.

4 Arzheimer 2009.

5 Dollard 1939. 
theory assumes that conflict is instrumental between groups in direct competition over resources ${ }^{6}$.

Social background explanations have been used by more active contemporary theorists in the field of far right studies, such as Minkenberg, Rydgren and Mudde, who have all linked increasing support for the far right with the process of modernisation and a rapid change that it has caused in societies globally ${ }^{7}$. These theorists claim that recent social and political changes make individuals more prone to radicalism because of the perceived threat and insecurity they produce ${ }^{8}$.

Socio-structural explanations account for the presence of ethnic minorities and structural and systemic issues that increase support for the far right, especially in Western Europe. This category includes economic chauvinism and anti-immigration sentiments in particular 9 . These explanations rely on studies that show that the number of migrants and asylum seekers is directly related to the increased support for the far right ${ }^{10}$. While these theories were used when describing and characterising the far right and its supporters in the West, similar patterns are also present in Eastern-Central Europe ${ }^{11}$.

\section{Historical Development and Theoretical Concepts}

After the end of the World War II, the extreme far right needed to reinvent itself in order to overcome social and political marginalisation, especially in Western Europe. A new framework that allowed for electoral success was established in 1970s; it incorporated elements of ethnonationalistic xenophobia with anti-political establishment populism, allowing for the electoral success of the French Front National in 1984. The new approach included proactive participation of the far right actors in the anti-immigration debates. These debates started occurring in the mid-1980s $\mathrm{s}^{12}$ and spread to the movements and parties in Eastern and South-Eastern Europe. This is partially due to the European integration process which has produced societal desire for delineation in order to separate cultures, religions and nations from each other as a result of the fear of loss of control over

6 Golder 2016; Yilmaz 2012.

7 Minkenberg 2000; Rydgren 2005; Mudde 2007.

8 Toots and Bachmann 2010; Arzheimer and Carter 2006.

9 Golder 2016; Arzheimer 2012.

10 Arzheimer 2018; Lubbres 2017.

11 Livanios 2002.

12 The European Union has undergone a series of negotiations, policy changes and agreements that have served the purpose of carefully balancing internal integration of the EU Member States and protection of their external borders. The Schengen agreement of 1985 was the first step towards European integration and encouragement for European states to promote and allow free movement across their borders. However, this systematic integration has produced a societal desire for delineation, to separate cultures, religions and nations from each other, which only grew stronger after the beginning of the migration "crisis". 
national borders. The far right has taken advantage of these fears, presenting immigration as a primary threat to the European culture, casting Muslim immigrants in particular as incompatible with the European social and cultural norms and therefore unable to ever fully integrate into the European society ${ }^{13}$.

The 1990s and the high influx of refugees from the Balkans allowed far right parties to take a strong stance on migration issues, which then made it possible for them to gain mass support. Such was the case of the Austrian Freedom Party, which entered the Austrian Government coalition in 1999. The global recession of 2008 further intensified economic grievances and allowed these parties to achieve significant electoral success. In Western Europe, this caused many other parties to form coalitions and shift to the right in an attempt to recapture support and votes, which led to an intensified presence of far right parties in previously strongly liberal parliaments ${ }^{14}$. Due to these developments, most research on the far right in Western Europe focuses on understanding the voting patterns and the electoral success of far right parties ${ }^{15}$.

The studies that focus on Eastern European far right follow a similar approach, but they are much more limited in both scope and quantity. Eastern European far right is considered to be less developed than its Western counterpart. When the 1990s brought regime changes to Eastern Europe, the systemic transition to democracy pushed ultranationalist agendas and approaches to the margins. Cas Mudde described this in 2005, stating that: "racist extremist parties are not really a major political force in Central and Eastern Europe. Indeed, if compared to their 'brethren' in Western Europe, they look somewhat pathetic: (far) more extremist, but (far) less successful"16. For this reason, lack of development of far right movements into strong political parties and coalitions such as those in Western Europe is often attributed to their stronger anti-democratic approach and more militant nature ${ }^{17}$.

Despite their different development paths, far right parties in both parts of Europe have considerable ideological affinity, mostly in terms of their shared animosity towards "nonEuropeans", primarily European Muslims and Americans. Muslims are often portrayed as anti-Western, intolerant, inassimilable and highly fertile, thereby threatening to demographically take over the European countries. Unlike the supposedly "barbaric" Muslims, the US is portrayed as the promoter of "corrupted" forms of modernity, such as the despised move towards globalisation or the "horrors" of multiculturalism ${ }^{18}$.

\footnotetext{
13 Yilmaz 2012.

14 Ibid. Williams 2006; Minkenberg 2017.

16 Mudde 2005, 269.

17 Ishiyama 2009; Bustikova and Kitschelt 2009.

18 Stefanović 2008.
}

15 For more information see: Akkerman 2012; Akkerman and de Lange 2012; Bale et al. 2010; Carter 2005; Downs 2001, 2012; Meguid 2008; Minkenberg 2002b, 2006; Mudde 2007; Schain 2006; 


\section{Renewal of the Far Right}

The far right has undergone a significant renewal as a result of modernisation, and particularly due to technological developments that took place in the past two decades. These developments allowed for new communication strategies as well as the creation of a global network that enables learning and provides the ability to exchange both knowledge and information, as well as to organise and mobilise support across national borders ${ }^{19}$. The common claim of the far right movements globally is that they speak for the "silenced majority" - those who have been pushed to political and social margins, and whose voice has been ignored by the mainstream media and politics. This way, they claim legitimacy in a democratic system and appeal to those who oppose the establishment and the political elites.

The anti-immigration approach has been particularly useful, as it allows the far right to claim that they speak on behalf of the nation against the political elites, and that they voice concerns about the issue that the political elites seem to be avoiding (usually to appear liberal or to avoid being labelled politically incorrect). When making arguments against migration, most far right groups rely on idealised narratives of the past, portraying the "other" as a threat to one's national, cultural, and religious identity ${ }^{20}$. The fear of migrants is strengthened by the fear of globalisation, which the far right characterises as a US led initiative for the purpose of creation of the New World Order which seeks to destroy national and cultural identities through the "import" of migrants ${ }^{21}$. While this might have slightly changed with the new US administration, the return to national borders and prevention of Western influence through globalisation remains the key issue on the agenda of the far right.

Migration and integration debates of the far right therefore focus primarily on debates over loyalty to the nation, national belonging, and cultural, religious and national traditions. These debates are most often framed around in-group - out-group debates, in which outsiders are presented as a threat to the survival of the nation itself $\mathrm{f}^{22}$. Such contemporary narratives focus on recent terrorist attacks and events that involved Muslims, as a way to emphasise the "incompatibility" of Islam with the European culture and the dangers that failed integration presents for host communities. Focusing on immigration allows the far right to identify not just the external enemies, but also the internal ones. In the case of Europe, the perceived internal enemy is usually the political elite, which have "betrayed" the nation ${ }^{23}$, while the external enemy is the "flood" of migrants and refugees sent to dilute and destroy the European civilisation.

19 Minkenberg 2000.

20 Kinnvall and Nesbitt-Larking 2013.

21 Mullins and Jones 2009; Mudde 2000.

22 Huysmans 2006.

23 Kinnvall 2015. 
There are several factors that differentiate the new far right from the old, but the two that are most researched and discussed in literature are: the organisational diversity of far right groups and their international character and appeal. A wider variety of actors and improved communication strategies allow the far right to cut across party spectrums, and for single issues such as abortion or immigration to gain new importance and serve as a mobilising force for numerous far right actors, across national borders. This is how the "migration crisis" helped a wide variety of far right actors to surface, provide resistance to European multiculturalism, and mobilise Euroscepticism within and beyond the borders of the European Union.

In terms of ideology, what most strongly differentiates the new far right from the old is its abandonment of biological racism and white superiority, and the adaptation of emphasis of incompatibility of cultures and resistance to cultural and ethnical mixing. According to Cas Mudde, the new "populist radical right" ideology is a combination of nativism, authoritarianism and populism, of which nativism is considered to be the key feature. It holds that "states should be inhabited exclusively by members of the native group ("the nation") and that non-native elements (persons and ideas) are fundamentally threatening to the homogenous nation-state". ${ }^{24}$ Therefore, the myth of a homogenous nation is placed before its individuals and their civil rights ${ }^{25}$.

\section{Eurasianism and Dugin's Influence on the Far Right}

Given that the "migration crisis" has set in motion numerous factors that served as a strong mobilising force for the far right in the European Union, most researchers and journalists have focused on understanding the social and political factors of the phenomenon in Western Europe. For a long time, there were only a few comparative studies that focused on Eastern Europe ${ }^{26}$, but more have been produced in the last decade ${ }^{27}$. However, many of these studies still lack a comparative approach to understanding how the far right develops and collaborates in the region and between regions. There are also few studies that demonstrate the impact of the far right on the social and political climate in Eastern Europe, with the exception of the recent contributions of Mudde and the recent works by Minkenberg, Pirro and Pytlas ${ }^{28}$.

The relatively "underdeveloped" Eastern European and Russian far right might seem inferior to the Western parties and movements, but with recent changes on the global political and social scene, and the shifts in geopolitical order, the far right in these countries has a potential to develop much faster, and has far more room and opportunities

24 Mudde 2007, 19.

25 Minkenberg 2000.

26 Ramet 1999; Mudde 2005.

27 Mareš 2011; Pankowski 2010; Minkenberg 2017; Sum 2010.

28 Mudde 2005, 2007; Minkenberg 2015; Pirro 2015; Pytlas 2016. 
to do so than its Western counterparts. In addition, in most cases it already has strong connections with the ruling parties, and therefore the potential to alter political and social fabric of the society to a much greater degree.

Russian nationalism developed largely based on the narratives of great victory over fascism, and it rests on the myths concerning the great Russian nation and its victories in the World War $\mathrm{II}^{29}$. The far right relies on the mix of non-Marxist socialism combined with populist nationalism and narratives of a future marked by a new world order in which Russia will finally claim its rightful leadership role. In the 1990s, most Russian nationalist movements were slowly shifting toward new right ideological approaches, with Aleksandr Dugin as one of the ideological fathers of the Russian new far right. Dugin occupies a complex place in the Russian political and social life. He runs the Centre for Geopolitical Expertise and lectures at the Military Academy for the General Staff, which has allowed him not only to earn respect in the military circles, but also to build connections and solicit financial support for his projects ${ }^{30}$. Many scholars have portrayed Dugin as the principal advisor to Putin, while others claim that his influence is limited to the academic circles and international relations, where he is presented as a great theorist. Whether or not Dugin has a strong influence on Putin might be irrelevant, considering that he is one of the most influential theorists who has impacted the far right ideological and structural organisation across Europe ${ }^{31}$.

Dugin was one of the first theorists to include Western traditionalism in the Russian new right, as he and a small group of other thinkers started incorporating parts of these narratives in the 1970s, to later include Western thinkers such as Alain de Benoist, the founder of the French New Right, in Russian nationalist thinking. Dugin subjected the entire far right spectrum to very harsh criticism. In his writings, he denied the importance of the distinction between left and right and defended militant Euroasianism without hiding his admiration for German interwar leftism and even the Nazi leftists ${ }^{32}$. Dugin and his collaborators transformed Russian nationalism by shifting its focus from antiWesternism to anti-migration, which provided a platform for the Russian far right to connect with its European and American counterparts. After this shift, the far right also adopted now universal terms used by the global far right to refer to migration such as "flood", "invasion" and "occupation", perceiving it as a threat to the Russian nation since it represents a far greater conspiracy - against the Russian people and European civilisation

29 Some of the main scholars on the Russian far right are John B. Dunlop (Hoover institution), Alexander Yanov (City University of New York), Valerii Solovei (MGIMO), Pal Kolsto (University of Oslo), Peter J.S.Duncan (University of Cambridge London), Stephen Hanson (College of William and Mary), Veljko Vujacic (European University of St. Petersburg), and Mar Bassin (Sodertorn University at Stockholm).

30 Laurelle 2008.

31 Even during the five-month period of data collection for this study, Dugin paid three separate visits to the region, two of which were in Belgrade, the Serbian capital.

32 Laruelle 2010. 
in general ${ }^{33}$. In this context, civilisation refers to cultural and ethnic differentials. This idea of civilisation rests on the belief that every nation has its specific characteristics that can only be perceived if viewed separately of other cultures. This line of thinking originated in the West, in the elements of the far right in Europe inspired by Alain de Benoist and centred on the Group for the Research and Study of European Civilisation (GRECE); it abandoned the theme of biological racism and replaced it with the belief that a civilisation is a living organism with its own essence, which must be protected from any contact with other worlds ${ }^{34}$.

Although the Russian political stance has been isolationist, and far right movements do not want to admit any sort of connection with the West or Europe that might make them appear "Europeanised", Russia has been an important hub for meetings and cultivation of the far right ideology. In addition, within Russia itself, those whose isolationist stance is grounded in anti-Westernism are less relevant and successful than those who have embraced the new anti-immigrant platform that unites the far right on the global scale ${ }^{35}$. It is not surprising, then, that the Russian and European far right actors both see Serbia as a perfect place to establish a strong presence - it is not just a "fertile ground" for strong nationalist policies, but also a perfect place for convenings and meetings of different actors who might not necessarily wish to be perceived as collaborators but do want to learn from and influence one another. Most of the members of the far right network (especially the European actors) rely heavily on Dugin's Fourth Political Theory. The theory argues that all the political systems of the modern age are products of three distinct ideologies: the first, and oldest, is liberal democracy; the second is Marxism; and the third is fascism. The Third Political Theory is what Dugin, in his Fourth Political Theory, calls Fascism and National Socialism. His Fourth Political theory suggests that the world today finds itself on the brink of a post-political reality - one in which the values of liberalism are so deeply embedded that the average person is not aware that there is an ideology at work around him/her ${ }^{36}$. As a result, liberalism is threatening to monopolise the political discourse and drown the world in a universal sameness, destroying everything that makes different cultures and peoples unique. According to Alexander Dugin, what is needed to break through this morass is a fourth ideology - one that will sift through the debris of the first three and look for elements thereof that might be useful, but which will, at the same time, be innovative and unique. Dugin foresees that the Fourth Political Theory will use the tools and concepts of modernity against itself to bring about a return of cultural diversity against commercialisation, as well as the traditional worldview of all the peoples of the world - albeit within an entirely new context. Following this theory, the anti-immigration and nationalist movements described in this study all believe that the return to traditional values and mono-ethnic states is the only way to preserve national and ethnic identities. Members of the far right who have participated in this study stated

33 Laruelle 2015.

34 Dugin 2014.

35 Kolstø and Blakkisrud 2016.

36 Dugin 2012. 
repeatedly that Serbia represents fertile ground for this ideology and a good place to start some of the first closed-off communities modelled on anarchist communes, which will signal the beginning of national rebirth.

\section{Migration and the Far Right in Serbia}

\section{The Far Right in Serbia Prior to the "Migration Crisis"}

While strong nationalist sentiment was one of the causes of the civil wars in the region, the arrival of Serbian refugees from Bosnia, Croatia and Kosovo in the 1990s strengthened victimhood narratives and created a social and political atmosphere that trapped Serbia in a strong nationalist political landscape which has lasted to this day. Research in other parts of Europe suggests that refugees expelled from their homes by "ethnic enemies" are likely to be radicalised by their traumatic experiences, and are thus more likely to support radical nationalist politics. Historical examples such as Hungary or Western Germany indicate that the support that refugees have given to extreme nationalists in the 1953 and 1955 elections support this theory as well. ${ }^{37}$ In Serbia, refugees who arrived joined their families and did not remain in refugee camps and government centres. The presence of family members and the refugees' traumatic negative experiences have arguably had a radicalising effect on the Serbian society, providing support for the ideas and the agenda of the Serbian Radical Party.

The economic crisis that occurred in Yugoslavia was exploited by the nationalists to capture power, while the Milošević's regime, NATO bombings and sanctions that followed resulted in an economic decline, inflation and a very high unemployment rate. This high unemployment rate was accompanied by expectations and attempts to maintain the socialist system and provide services that were available at the time of Yugoslavia. The crisis produced a situation where the traditionally somewhat more inclusive Yugoslav identity was rapidly replaced by an exclusive extreme nationalist Serbian identity. Historical revisionism which was already strong in the 1970s and 1980s allowed for growth of animosity towards other ethnic groups, as the historical episodes that involved other Yugoslav peoples were rewritten in such a way that they were portrayed as betrayers and centuries old enemies who have "turned" on Serbs ${ }^{38}$. The Yugoslav identity was portrayed as "false" while the return to "true" Serbian identity was "recommended". These narratives

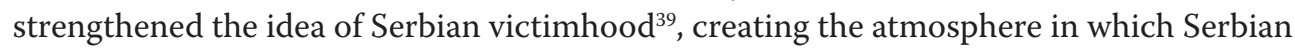
Radicals presented themselves as the "true" patriots.

In addition to the Serbian Radical Party, other far right organisations were formed in the 1990s, many of which acted as paramilitary organisations, openly promoting and

37 Brubaker and Laitin 1998.

38 Banac 1990.

39 Brubaker and Laitin 1998. 
committing acts of violence in Bosnia and Herzegovina and Kosovo in particular ${ }^{40}$. After the end of the Yugoslav wars, these parties and organisations splintered, many of them morphing into cultural and non-profit organisations, student movements, or citizen initiatives. The radical nationalist camp briefly united once again, until the early 2000s when Milošević was handed over to the Hague. Different actors were temporarily forced to unite, but soon after they all returned to operating as separate entities, often in opposition with each other. In spite of all the divisions that existed on the Serbian far right scene, the one thing that united them all was their strong anti-Westernism and the updating of national narratives strengthened by the NATO bombing of Serbia as a response to the Kosovo crisis $^{41}$. Such groups also promote traditional family values, religious fanaticism, and condemn the LGBTQ population in Serbia ${ }^{42}$.

Besides the fact that far right groups can be classified in many different ways (as fascist, neo-Nazi, extreme nationalists, soccer fans, etc.), there is a significant overlap between their members which makes it difficult to track how many movements there actually are, and how active their networks happen to be in different parts of the country ${ }^{43}$.In addition, many of the above movements and organisations are established by party members who are often members of the Parliament themselves, which at times makes them tightly connected to mainstream politics and thus difficult to recognise as "radical" or "extreme". While conducting field research, I have met members of the Serbian Radical Party who were also leaders of anti-immigration online campaigns and movements, but who claimed to be doing that in their personal capacity. Yet, several minutes into the interview, they would disclose that the higher leadership of the party had screened the content of their websites and pre-approved all their public speeches given as part of anti-immigration organising. Meanwhile, the party itself did not directly participate in the study, as they "were not active" regarding the migration issue ${ }^{44}$.

\section{Characteristics of the "New Right"}

Under the Serbian Anti-Discrimination Act, it is officially illegal for neo-Nazi or fascist organisations to publicly organise, or display fascist emblems in public, but no charges are pressed when this happens. Movements that are banned continue to operate either under a different name or their members move to other organisations and continue their activities

40 For more information see Babić 2015; Bakić 2009; Djokić 2012; Džombić 2014.

41 Biserko, d.d 2014.

42 Džombić 2014.

43 Čolović 2002.

44 Interview conducted on 24 July 2017 with the member of the Serbian Radical Party who has started his own anti-immigration movement in Belgrade. 
undisturbed $^{45}$. Legal measures against these movements have a dual effect: for some it means pushing their activities underground (such as Srbska Akcija), while for others it means adjusting them slightly to the political climate in the country and transforming themselves into a viable party option (as was the case with Dveri). In both cases, their outreach to potential supporters is based on the premise that they are "fighting against the political elites". Legal action against them is seen as "proof" of restriction of freedom of speech and marginalisation by the political elites. In this sense, they follow the global trend of the far right in which they present themselves as representatives of the people, true patriots who are protecting the citizens' freedom of speech and representing their interests. In the current political and social atmosphere, their ability to speak against the system and the political elites make them look appealing to individuals who are dissatisfied with the political and economic situation in the country. Young population is particularly susceptible to the influence of such movements and their narratives. Unfortunately, there is very little research into the mobilisation to the far right and factors that determine support for far right actors.

Serbian far right extremists have focused on national minorities as a way to gain popular support. Presence of minorities within Serbia, and of Serbian minorities on what is perceived as historically Serbian land, has served as a mobilising factor for the Serbian Radical Party.

Muslims and Roma communities were the most common targets of Serbian far right propaganda, which resulted in the development of "welfare chauvinism" similar to that seen in Western and Eastern Europe. The "welfare chauvinism" in Serbia is manifested through the monopolisation of access to services by the economically vulnerable majority, which tries to portray minorities (such as Roma) as "disloyal" to the Serbian state and therefore "undeserving". ${ }^{66}$ While Western European welfare chauvinists attempt to legitimise exclusion by arguing that only the "long established" population is entitled to social services since they had created these services themselves by paying heavy $\operatorname{taxes}^{47}$, Serbian welfare chauvinists argue that presumably disloyal minorities do not deserve to benefit from Serbian state welfare. During an interview with the Serbian anti-trafficking human rights organisation ATINA, staff pointed out that the narrative of radical far right organisations that oppose their work has changed from criticising them for supporting "undeserving Roma" to neglecting "our Roma communities" to support undeserving "fake refugees" in Serbia.

In addition to its antagonism toward minorities, the Serbian far right is defined by

45 Despite strong interconnectedness of these movements, they are able to operate in such a way because of their strong ties to the mainstream political parties in Serbian government. The legal restrictions do not have a strong effect as individuals associated with the organisations and movements in question continue to work through other, rebranded, movements.

46 Stefanović 2008.

47 Mudde 2000. 
its strong anti-Westernism, which is most often expressed through attacks of nonprofit organisations and their activists. Individuals and organisations that work on and advocate for democratisation and protection of human rights are increasingly becoming targets of the Serbian far right. These organisations and individuals are referred to as "foreign mercenaries" and seen as a foreign sponsored effort to destroy the fabric of the Serbian society and national identity. Recent physical attacks of the far right movement Alternative (Alternativa) on activists of the Youth Initiative for Human Rights show that this animosity has intensified over the last couple of years ${ }^{48}$. Attacks on NGO activists and independent journalists often remain unresolved due to the lack of political will ${ }^{49}$. It is worth noting that most of the research on the contemporary far right in Serbia is also conducted primarily by the civil society sector - precisely by activists, researchers and journalists ${ }^{50}$. Self-censorship has increased in independent and investigative media, and consequently even the investigative journalistic pieces on this topic tend to be extremely limited in scope ${ }^{51}$. The fact that NGOs remain the most active in this field also creates increasingly more polarised social and political environment where their work is labelled as "anti-state" and "anti-Serb", which makes awareness-raising and countering extremism all the more difficult. As a representative of the Zavetnici movement stated in an interview for this study: "NGOs are very well paid to do this-their goal is the same as the goal of Soros - to get Europe to take one million migrants per year, because they think that moving these people in is a solution for European demographic issues. Their story is absurd. NGOs have no influence - they are well paid, but their representatives talk as if they do not live here and they make ordinary people agitated and angry, and they harm the migrants even more by saying that the state should do more while our own people live under horrible conditions. ${ }^{52}$ It is precisely this sort of narrative and approach that has allowed the Serbian far right to "rebrand" itself, and strengthen old and establish new connections with the European far right actors.

48 Stević, Irena. 2017. "Youth Initiative for Human Rights: Attack on our activists for war crimes discussion.” Insajder, 21 April. Available at: https://insajder.net/en/site/focus/4273/.

49 United States Department of State, 2017.

50 One of the most comprehensive reports, and the most recent one, produced has been done by the Helsinki Committee for Human Rights in 2014. Other organisations produced shorter reports on different aspects of the radical far right activity, but there is very limited research available.

51 For more information see the report created by the Media Governance and Industries Research Lab - Far-right Nationalism and Populism in Europe: Assaults on Press Freedom, available at: https:// mediagovernance.univie.ac.at/fileadmin/user_upload/p_mediagovernance/PDF/Far-right_Nationalism.pdf.

52 Intrview with the representative of the movement Zavetnici, conducted on 21 July 2017. 


\section{Migration Profile of Serbia and the Appearance of "New Refugees"}

Since the breakup of Yugoslavia, Serbia has been one of the world's main countries of origin of refugees, as well as one of the most important host countries. The number of refugees in the country has significantly decreased since 1996, when there were 524,000 registered. The decrease is a result of regional return processes, resettlement programmes and naturalisation. Still, more than 300,000 persons in Serbia await long-term solutions. Most of these people are Serbian refugees from the neighbouring countries; however, their presence does not seem to create the same controversy as does that of the refugees from the Middle East ${ }^{53}$. In 2015 and the first quarter of 2016, more than 920,000 refugees and migrants - primarily from Syria, Afghanistan and Iraq - passed through Serbia on their way to Central Europe ${ }^{54}$. Before the closure of the Balkan Route, most continued their journey to Western Europe in less than 72 hours. After the closure, the average stay extended from a couple of weeks in 2015 to over a year by the summer of 2017, as migrants got stuck at border crossings and then made their way to Serbian towns. Interviews conducted as part of this study suggest that migrants show little interest in settling in Serbia, because of poor economic opportunities, lower standard of living than in the rest of Europe, a complicated asylum process, and lack of good integration approaches ${ }^{55}$.

Both asylum seekers and asylees (persons who have been granted asylum) are legally entitled to healthcare, shelter in an asylum centre, an asylum ID, free primary and secondary education, social assistance, and freedom of movement within Serbia ${ }^{56}$. However, only a small number of people have actually received asylum ${ }^{57}$. Asylum applications are usually rejected either because migrants are categorised as economic migrants, or because they had previously been in a safe third country and are thus considered to have had the

53 Organisation for Security and Co-Operation in Europe Mission to Serbia 2017.

54 European Commission 2018.

55 By June 2017, there were fewer than 7,000 migrants in Serbia, of whom over $40 \%$ had been present longer than six months, and $20 \%$ for over a year. The number of refugees, asylum-seekers and migrants in Serbia has been declining since spring 2017, and has stabilised during the summer (UNHCR 2017). However, September 2017 saw an increase in arrivals. According to one NGO, there were 954 new arrivals in September 2017 alone (Praxis 2017). Out of the registered migrants in the country, 95\% have not applied for asylum but only expressed their intention to seek it. In September 2017, Serbia had 5 asylum centres and 18 reception centres.

56 Despite its constitutional commitments, Serbia lacks a coherent migration strategy. Article 57 of the Constitution guarantees the right to asylum, through the Asylum Act, the Foreign Nationals Act, the Migration Management Act, the General Administrative Procedure Act and the Administrative Proceedings Act. The Ministry of Interior has drafted a new asylum law which was expected to be adopted by the end of 2017, however, changes to the EU regulations related to migration might delay this, as Serbia would then need to redraft its new migration law and allow time for it to be approved by the EU and domestic governing bodies.

57 Asylum Information Database, 2018. 
opportunity to seek asylum there ${ }^{58}$. Due to these legal difficulties migrants generally avoid applying for asylum, which results in a limited ability of humanitarian agencies or the government to find and protect vulnerable people. According to information received from the Asylum Protection Centre APC/CZA, only 164 people submitted requests for asylum, out of 3,830 who have expressed the intention to do so in $2017^{59}$. That year, asylum was granted only to two men, one from Syria and one from Afghanistan ${ }^{60}$, while 42 persons were granted refugee status/subsidiary protection, of which 25 were supported by UNHCR partners ${ }^{61}$.

Many migrants lived in informal arrangements near the centre of Belgrade. The government tried to move them into reception centres, but most refused to leave as they preferred proximity to the city centre and potential smugglers. For example, some 1,500 migrants have been living in wooden barracks behind the train station since 2015 . As the period of the migrants' stay in Belgrade's city centre lengthened, health and security problems arose. Harsh winter conditions at the beginning of 2017 (temperatures below $-16^{\circ} \mathrm{C}$ ) created hazards for those living outdoors or in non-weatherised shelters. Government officials were also concerned about possible outbreaks of body lice and substance abuse. Fights and robberies involving migrants and local smugglers became more frequent, making the local population nervous. In addition, anarchist activists from different European countries who volunteered in Belgrade moved into the barracks and organised political actions, such as hunger strikes and refusal to abandon the barracks upon government orders. The Commissariat for Refugees managed to move this group of migrants out of the city in May 2017, when the barracks were demolished to create space for a new development project called "The Belgrade Waterfront", and the migrants who lived in the barracks were relocated to the town of Obrenovac. This was especially important for Belgrade, as frequent fights between the migrants and other disturbances kept being reported to the police by locals who had become increasingly impatient with the lengthening of the waiting period that followed regional border closures. By September 2017, most migrants and refugees in Serbia lived in government provided centres, which are free (of charge) and generally safer than the city centre.

While migrant-host relations in Belgrade are still generally positive, reports of security incidents and resistance from local populations are much more common in smaller

58 The list of safe third countries issued by the Serbian government in 2009 includes all countries that border Serbia. Thus, a migrant coming through these bordering countries does not qualify for asylum -- only if he or she arrives by airplane, which is not likely because Serbia lacks direct flight connections with most countries of origin.

59 Asylum Protection Centre is an NGO that works directly within the asylum procedure. This data seems reliable, since every person who submits a request for asylum uses services either of APC/ CZA or the Belgrade Centre for Human Rights. The data collected by the Asylum Protection Centre matches government data based on registrations recorded by the Asylum Office, the government body in charge of refugees and migrants.

60 Rudić 2017.

61 UNHCR Serbia 2017. 
border towns in Serbia. Refugees in smaller towns live in asylum centres that offer fewer services. Non-profit representatives who have participated in this study have reported that locals in small Serbian towns feel uneasy when they see groups of young migrant men walking around town or spending time in local bars. Alcohol and drug abuse is becoming more common in these places due to idleness in asylum centres. The increased reporting of incidents involving migrants has thus served as a mobilising tool for the far right groups in these towns and beyond, reflecting in strong activism in Belgrade itself. The far right actors and anti-immigration movements organised their main activities mostly in Belgrade, where they were able to bring in, or connect with, political actors and activists from Europe.

\section{Serbian Far Right and the "Migration Crisis"}

In the absence of strong and active engagement of the EU in Serbia, Russian influence is becoming much more obvious. Russia has been taking proactive steps to not just influence Serbian political and social scene through its traditional approaches based on shared religion and cultural heritage, but also through intensified social and mass media campaigns that foment anti-Western and anti-European sentiments. Russia's strategic objective in playing the role of disruptor in the Western Balkans is to compel the creation of a new order which recognises Russian leadership ${ }^{62}$ and supports its repositioning as a regional power ${ }^{63}$ or - at the very least - halts the progression of Western ideology and institutions from encroaching further into Russia's sphere of influence. While strong connections between the Russian and Serbian far right had been established earlier, through different religious and other cultural organisations and their activities, the connections with European far right movements are somewhat rare and generally weaker.

The Serbian Radical Party has been active in establishing connections with the European far right movements and organisations since the 1990s, but there no particularly strong collaborations have been established due to relatively exclusionary politics of the EU towards the Western Balkans ${ }^{64}$. However, all this changed with the arrival of the migrants from the Middle East. As Europe struggles to push out individuals and movements associated with the far right, they are starting to make their way to Serbia where they are establishing their offices, new movements and organisations, and strengthening connections with far right actors globally. In this sense, Serbia is becoming a "conference room" where Russian and European far right activists connect and strategise together.

As most of the anti-immigration organising was happening online, I decided to reach out to the administrators of most active Facebook "movements" in this field. As a result, I connected with representatives of three far right movements from Europe that had

62 Atlantic Council 2017.

63 European Council on Foreign Relations 2018.

64 Bakić 2009. 
strong ties with Serbian anti-immigration activists. Through formal interviews and informal conversations with the representatives of these movements, I was able to gather more information about European movements and parties to which they are connected, which allowed me to construct and analyse the social network that these collectives and individuals form.

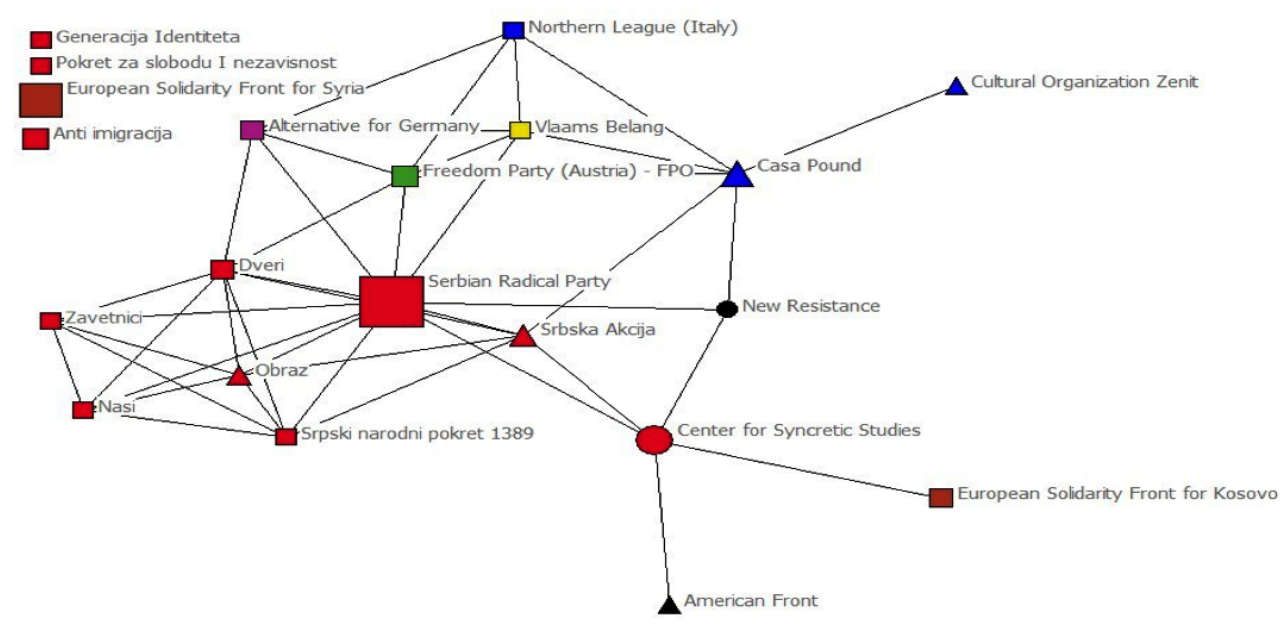

Figure 1: The network prior to anti-immigration movements

(Shapes: square - political party; triangle - fascist organization; circle - think tank; colours: red - Serbia; black - USA; orange: multiple locations in Europe; green - Austria; yellow - Belgium; purple - Germany; blue - Italy)

The social network graph in Figure 1 presents the network consisting of 21 movements - Serbian and European. The starting points for network building have been the antiimmigration movements. After talking to their leaders and asking them about the individuals and movements that inspire and support them, I started constructing the network. The movements included in the map are, therefore, those that research participants have named as inspiring or actively supportive, and with which they had some sort of connection - either public support on the internet, or direct collaboration between members and organisation of events, protests, public speaking engagements, humanitarian actions, etc. The ties represented here were created based on the movements' and parties' claims of collaboration and based on desk research which confirmed these connections by performing an in-depth analysis of their internet presence and social media activity. The ties presented here have been formed prior to 2011 and the Syrian conflict, and the network excludes anti-immigration movements. Such criteria serve to highlight the connections between organisations and movements that traditionally did not collaborate, but have been brought together as a result of anti-immigration activity and 
mutual connection to anti-immigration movements through which they now frequently operate.

Official parties such as Dveri in most cases refused to directly participate in this study, claiming that they are not active in the immigration field as it is not a relevant political issue for them. Organisations and movements that operate outside of political party structures took the lead in responding to the "threat" of the "migration crisis" instead, but even their activity was very minimal compared to the anti-immigration activity in Europe. This can partly be contributed to the government's insistence on showing respect for the migrants, which has prompted movements and parties to "wait" and see what the official government strategy would be. A research participant from the Serbian Radical Party stated as follows: "The party is too scared to act and be accused of racism, and they do not want the media to step on them too much with regard to migration by taking their words out of context as they usually do". Also, when asked if they [his party] participated in the protests that have been organised earlier, he assertively stated that he is not a part of the "racist and fascist scene" but rather a concerned citizen of his country, interested in the protection of his people and their interests ${ }^{65}$. Similarly, the representative of Zavetnici was critical of the government approach, highlighting the need for protecting Serbian citizens first: "We need to understand the state, because they do not want incidents, but we still need to know what is happening because the story that everything is great is not true -the state needs to protect its citizens, but the local communities around the centres know what is going on and the state has not done much for them" ${ }^{\text {. }}$. All interviews indicated that, similarly to the Russian case, the traditionally anti-Western and predominantly fascist organisations and movements are becoming marginalised by the increased "Europeanisation" of the far right.

65 Interview conducted with a member of the Serbian Radical Party on 24 July 2017.

66 Interview conducted with the representative of the Zavetnici movement on 21 July 2017. 


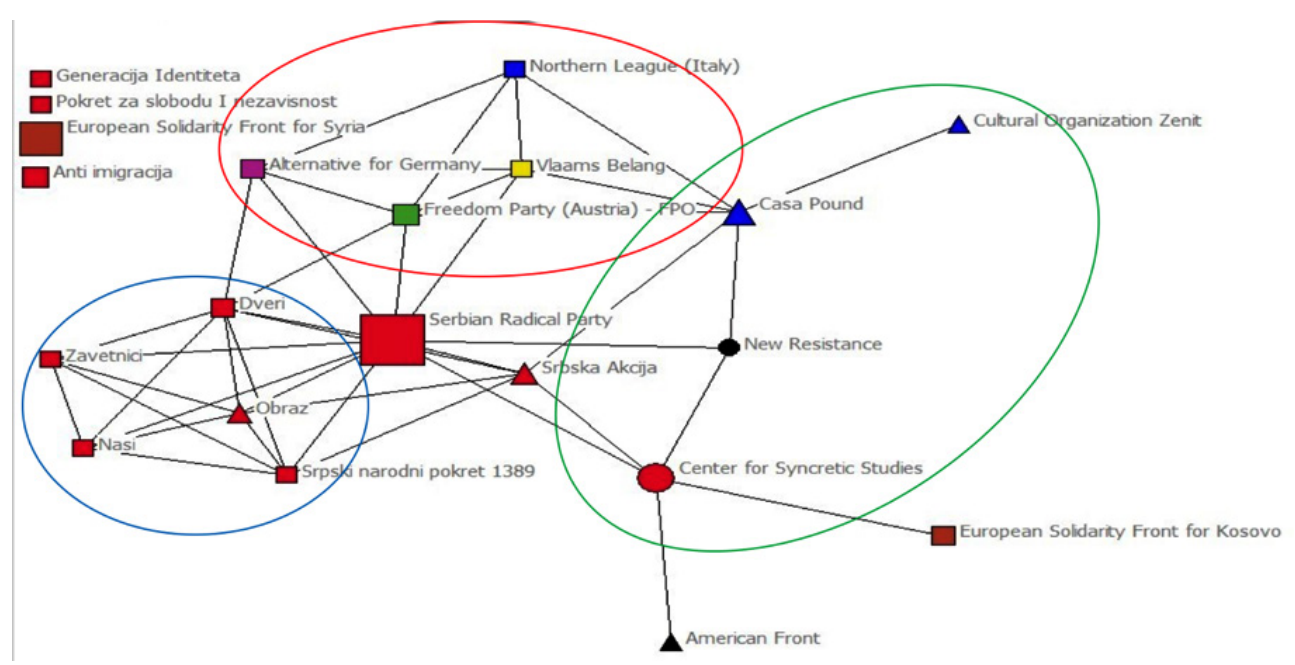

Figure 2: The network, segregated by geography/ideology

(Colour code: green - Italian fascist organisations; red - European nationalist parties; blue Serbian nationalist parties and organisations; shapes: square - political party; triangle - fascist organisation; circle - think tank)

The far right scene in Serbia and its European collaborators prior to 2011 have been clearly segregated based on the organisations' types and structures as well as ideological affinity. While the connections between some well-established parties and movements in Serbia and Europe did exist, they were primarily centralised around the Serbian Radical Party, the leading representative of the far right in Serbia since the 1990s. This party served as the main connector, bridging the gap between Serbian extreme nationalist organisations, European nationalist parties, and Serbian and European fascist movements and organisations.

However, all this started to shift with the introduction of anti-immigration movements into the network. Two specifically anti-immigration online "movements" that have started as Facebook pages and jointly organised debates and events and brought in European far right actors to Belgrade are: Initiative Anti-Imigracija and Generacija Identiteta. AntiImigracija is a Facebook page run by a member of the youth of the Serbian Radical Party. He stresses that his activities related to anti-immigration are performed in personal capacity, and are separate from Party activities and politics (although the Party is aware of the activities and actively screens the content of his speeches and public events). $\mathrm{He}$ uses the Facebook page as a way to gather and publicise news about incidents that occur not just in local communities in Serbia, but also in cities and towns across Europe. As he states, the goal of the page is to raise awareness about the consequences of migration and effects that a large number of migrants can have on a country. The page has been reported 
to and shut down by Facebook on several occasions, but he continues to revive it and post new content ${ }^{67}$. Similarly, Generacija identiteta focuses on migration: it delivers news about incidents, attacks, and what they define as overall negative outcomes of influxes of migrants into different communities, but they also place a very strong emphasis on the preservation of the Serbian identity and national interests as well as creation and preservation of a mono-ethnic state. The main chapter of this organisation is in France, but there are others in several European countries.

One of these "movements" played the key role in introducing the first European far right organisation that emerged and established a strong foothold in Serbia - The European Solidarity Front for Syria (ESFS). ESFS brought to Serbia one of the most interesting individuals involved in the anti-immigration scene - a Syrian woman Rima Darius, who was invited to Belgrade by the man behind the Initiative Anti-imigracija. Until the fall of 2017, Rima Darius and her husband Ruben Rosiers were members of the European Solidarity Front for Syria (ESFS). In his own words, Rosiers explained that he and his movement "support the Syrians in their war to keep their independence, unity and sovereignty, and against Western-backed terrorism". ESFS has established its presence in Great Britain, Germany, Malta, Belgium, Bolivia, Ecuador, Colombia and Cyprus, and has developed connections and collaborations with many other movements across Europe and the Western Balkans. In September 2013, an Italian delegation from ESFS travelled to Syria "in support of the legitimate Government of Bashar Al Assad and the Syrian people", where it met with the Syrian Prime Minister, Deputy Minister of Foreign Affairs and members of the ultra-nationalist Syrian Social-Nationalist Party.

Rima Darius joined one of the protests in Belgrade that was organised in 2016 by Naši, Obraz, and the Serbian Radical Party. The planned protest was banned by the authorities, but it still took place a week later under a different name, under the pretence of protesting the Government of Aleksandar Vučić as a regime that is anti-Serbian and oppressive. This served as an opportunity for Rima to visit Belgrade and give a speech before a couple of hundred gathered people. After going viral on YouTube, her speech received international attention. The video recording of it has been used by antiimmigration groups across Europe, and welcomed by groups such as PEGIDA and FPO (Freedom Party of Austria). It has brought her so much attention that she joined some of the nationalist parties in Europe, such as the FPO, in their campaigns against migration. In her speech, Rima urged Serbia and the EU not to take in refugees, as most of them are economic migrants escaping Syria. She urged citizens of Serbia to remember their own past and understand that Syria can only have a future if its people remain there to build it, which will not be possible if they leave the country to establish new lives across Europe. Her main argument echoed what the far right argues for globally: only the return to national borders can preserve national identities and ensure safety and respect for human rights and democracy.

67 Since the fall of 2017, the Facebook page also became a movement started by the same individual under the name Movement for Freedom and Independence (Pokret za slobodu i nezavisnost). 
ESFS was established by the members of the Italian Casa Pound - named after Ezra Pound - and Casa Pound's student organisation Blocco Studentesco. Their Italian spokesperson and one of the founders, Matteo Caponetti, belongs to the Associazone Culturale Zenit, a "cultural" organization that openly admits its connection to fascism. Zenit is also directly involved in the establishment and running of the European Solidarity Front for Kosovo (ESFK), which began to operate in $2013^{68}$. ESFK claims that it has no official Serbian members, but states that they do receive help from Serbs in Belgrade and Kosovo to organise and run their activities. Research participants who introduced me to the European Solidarity Front for Syria confirmed that it was at the humanitarian action organised by the European Solidarity Front for Kosovo that they met with the members of the Serbian Radical Party. It was at that time that Rima Darious was invited to Belgrade, where she gave her famous anti-immigration speech. Both ESFK and ESFS see Serbs from Serbia and Kosovo as perfect collaborators on their project, as they are European people who, in their opinion, still hold strong ties to their identity and fight to defend it. They recognise the Serbian struggle in Kosovo, see NATO aggression on Serbia as an example of struggle against Western imperialism, and draw strong parallels between the current events in Syria and those in Serbia in the 1990s. A representative of the ESFS stated in a conversation about immigration that Kosovo is a perfect example of what happens to a country when it agrees to take in refugees:"... Kosovo is lost to Serbia as a result of Serbian generosity, which led them to welcome Albanian refugees who in return organised, mobilised, expelled Serbian citizens out of Kosovo and took over Serbian land".

The first ESFS conference in Serbia, titled Truth about Syria, was held on 18 December 2013. The event was put together by Teša Tešanović of the Serbian Radical Party, the Centre for Syncretic Studies, the European Solidarity Front for Syria, and the New Resistance. The most important message of this conference was that "media in Serbia, acting mostly as an uncritical transfer agency citing Western sources, are ignoring the fact that Syria is the victim of an armed aggression, and are demonising it the same way Serbia was demonised in the recent past"69. Brought in by the Support for Syria and Bashar al-Assad from the People of Serbia (another online "movement" with some 8,000 supporters), ESFS met with its supporters in Serbia who later officially joined their activities. The Centre for Syncretic Studies, which hosted these first events and debates, was formed in 2013 and it is led by Joaquin Flores, founder and Director of the NGO Centre for Syncretic Studies and supporter of New Resistance, the believer in the Fourth Political Theory, and sympathiser of the Serbian Radical Party. New Resistance is an organisation that describes itself as a "loose network of American and Canadian fourth political theorists, national revolutionaries, Eurasianists, national Bolsheviks, left-nationalists, right-wing anti-

68 Katanić Aleksandra. 2016. "An interview with Matteo Caponetti, the representative of European Solidarity Front for Kosovo." Stanje stvari, 28 March. Available at: https://stanjestvari. com/2016/03/28/an-interview-with-matteo-caponetti-the-representative-of-european-solidarityfront-for-kosovo/.

69 J.V Capone. 2013. "Belgrade Panel Discussion: "The Truth about Syria." Centre for Syncretic Studies, 21 December. Available at: https://syncreticstudies.com/2013/12/21/belgrade-panel-discussion-the-truth-about-syria/. 
capitalists and non-dogmatic left-wing radicals who advocate a wide-ranging and multilevelled resistance to neo-liberal economic policies, Anglo-US imperialism and Zionist influence in the media and government".

The founder and leader of the New Resistance serves also as political adviser for the Centre for Syncretic Studies. His name is James Porrazzo, and he is a former leader of the American Front (AF). The AF is one of the oldest American racist skinhead groups, founded in California in the $80 \mathrm{~s}$, which has made a name for itself fairly quickly by building affiliations with better-known racist groups such as Tom Metzger's White Aryan Resistance. Much of its ideology was standard for racist skin crews of the day, emphasising hatred for blacks, Jews and other minorities. Under Porrazzo, the AF moved to Arkansas and became one of the few American radical-right groups to espouse the Third Position, which is far more common among the groups on the European racist right. The Third Position is a brand of neofascism that advocates racial separatism and racially-based socialism that is opposed to both capitalism and communism. In October 2011, Porrazzo said that he was dissolving the AF, and announced that all former AF members would, from then on, belong to his newly christened group, New Resistance ${ }^{70}$. Porrazzo currently holds that the Fourth Position, which he also describes as a kind of "left-nationalism", is the "future of the revolutionary struggle against globalism, capitalism and liberalism". His New Resistance supports authoritarian Syrian President Bashar Hafez al-Assad, mourns the defeat of Libya's late ruler Muammar Gaddafi, and praises Venezuela's leftist president Hugo Chavez. Followers are encouraged to read leftist classics by Karl Marx, Fidel Castro, and Che Guevara, all of which sit uneasily on his website next to fascist thinkers like Claudio Mutti and Julius Evola.

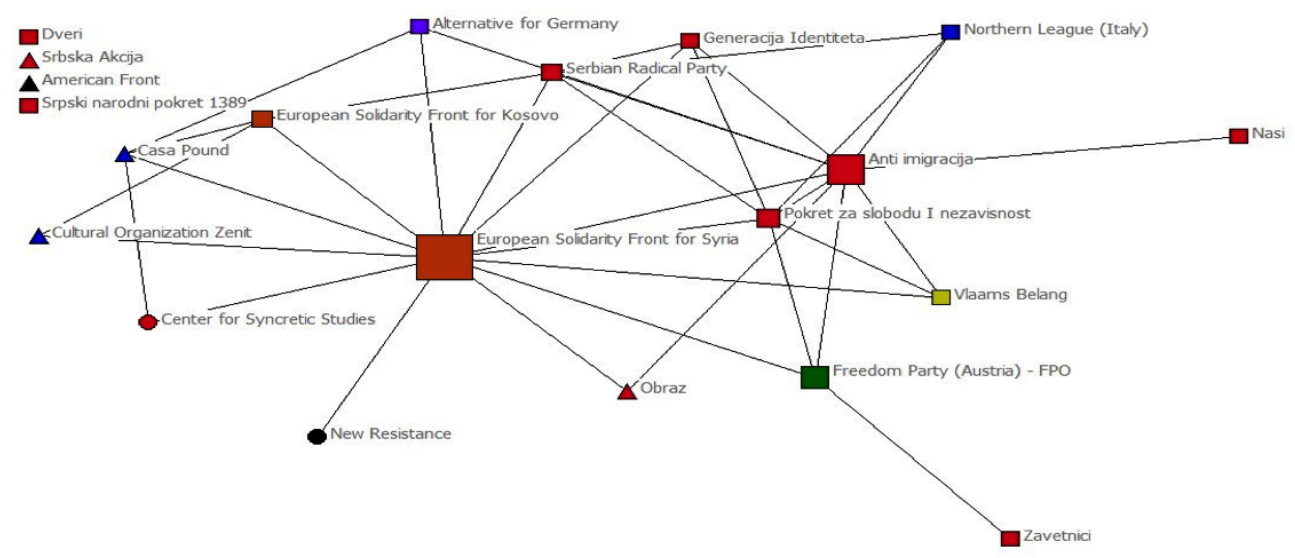

Figure 3: The network, after the anti-immigration movements became active in Serbia

As a result of the increased presence of anti-immigration movements and the European far right, the network of such actors in Serbia is becoming much less centralised. Looking

70 Tesanović 2014. 
at the network structure, one might ask: how do far right actors that in some cases even ideologically oppose each other, end up connected in a network, and why? This question is precisely what the anti-immigration platform approach addresses - focusing on antiimmigration is in the interest of all the far right actors, regardless of their differences in relation to certain internal or external political issues, and it provides a good strategy for building political unity of the far right on national as well as international level. However, more importantly, at the time of shifting global orders and increased questioning of the European liberal democratic order, anti-immigration platform offers connections to all actors interested in return to national borders, as well as increased focus on national identity as the most important citizenship requirement. It is therefore not surprising that Serbian far right actors are becoming increasingly more connected to those from Europe, as the European far right sees Serbia as "fertile ground" for a monoethnic state, out of which they could advocate for and support activities involving similar projects in Europe. Serbian far right actors, on the other hand, now have the opportunity to shake off the label of "backwardness" that was attached to them during the 90s and join the modernised, European network of movements.
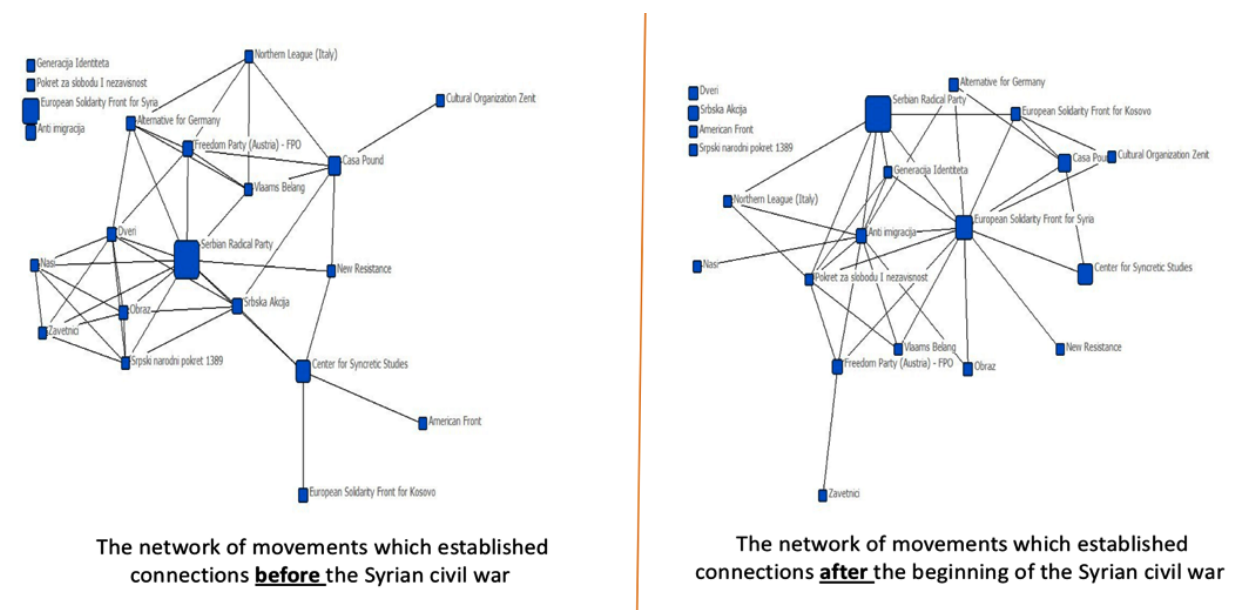

Figure 4: The networks before 2011 and after 2013

By comparing the networks shown in Figure 4, we can see that years 2011 to 2013 were marked by a transformation of ideological approaches as well as connections between the far right movements in Serbia and Europe. The changes on the global political scene and the commencement of the immigration crisis marked the year when Serbian and the European far right actors started developing various sorts of ties and relationships - those built and strengthened based on the anti-immigration platform. By the summer of 2017, when data to be used in this study was collected, it seemed that more established Serbian far right movements were still working on their narratives and strategic approaches to migration; however, European anti-immigration movements showed up in the country, as well as a small number of individuals with an established strong online presence, which allowed them to gain more traction and attract a wider audience for their cause. Their 
presence is precisely what created the shift in the network, making it less centralised and much better connected.

\section{Conclusion}

Anti-immigration activity proved to be a valuable mobilisation tactic for the far right, as it is easily adjustable to different contexts in different countries, and because it also allows for the association of movements across national borders, helping a wide variety of far right actors to associate with successful movements in other countries and step into the mainstream. While the platform served different purposes in different countries, the appeal was multinational and global. In some countries, the anti-immigration platform served as a successful mobilising tool because of religious intolerance, in some due to economic arguments, while in others cultural incompatibility and arguments about safety and security were used to "warn" against the "flood" of migrants who were overtaking Europe. In Russia and Serbia, the reason for transition from anti-Western to antiimmigration focused agenda was to ensure the relevance of far right actors in the global arena $^{71}$. Far right thinkers such as Dugin have understood that anti-Western agenda is no longer useful in the changing geopolitical order and climate. Transitioning to the antiimmigration platform was a far more useful project, as it allowed the same arguments to be made from a different perspective and with a network of international movements to back it up.

The mix of strategies, some of which have traditionally been used by leftist movements, is one of the most prominent characteristics of the "new right" globally. The uniting argument for a variety of far right actors globally is that multicultural liberal democracy is a "failed experiment", and that time has come to consider return to national borders as a viable social and political solution. Terrorist attacks have been used as "proof" of cultural incompatibility. Such arguments have been repeatedly expressed by research participants in this project: for example, a representative of the European Solidarity Front for Syria strongly argued that "they simply do not fit in", while a representative of the Serbian Radical Party emphasised that "they bring crime and violence with them" and that "their culture is inherently violent".72 The fear of destruction of the European civilisation and individual national identities is used to build momentum for mass mobilisation in support of defensive nationalism.

New far right actors often employ the language of the radical left, echoing some neofascist movements of the late 1960s and 1970s whose language and style were partly inspired by the 1960s counterculture. It is important to note, however, that most of the new movements claim not to be left, centre, or right, which provides them with an

\footnotetext{
71 Dugin 2014.

72 Interview conducted with the member of the SRS and the leader of a new anti-immigration movement on 24 July 2017.
} 
opportunity to use a mix of far-left anarchist rhetoric as well as far right, and therefore often appeal to both sides of the spectrum. In this sense, Dugin's influence is deeply felt in all parts of the network of movements represented in this study.

At the time when the data to be used for this project was collected, far right movements were in the process of arriving to Serbia, but their presence and activities were still "invisible" to those who were not seeking them out. By winter 2017, however, the situation had changed and big names such as Nick Griffin and James Dawson, who are well known British nationalists (often labelled as fascist) and have been chased out of Hungary in 2016, have found refuge in Serbia. While the rise of the far right in Serbia might have seemed less likely at the beginning of 2017, in only a couple of months new movements were formed, a strong anti-migrant platform was created, and new far right organisations have even started calling for murder of opposition parliamentarians who have questioned their activities and the presence of European far right actors in Serbia ${ }^{73}$. On 11 January 2018, local and international far right actors gathered to officially launch a new organisation called "Serbian Right". They did it with the support of local political leaders ${ }^{74}$.

The case study of Serbia included in this paper shows that the idea of Serbian exceptionalism has been the cause of much frustration, with serious social and political consequences for the Serbian people. While the Serbian far right had played a very important role during the conflict in the 90 s and has maintained a strong grip on power ever since, treating Serbia as an outlier and marginalising the region has only made it more prone to radical influences. Serbian nationalists have used victimisation narratives for their anti-Western platforms, with a strong focus on the NATO bombing of Serbia and support for independence of Kosovo as "proof" of Western aggression aimed at destroying the Serbian nation. European far right actors that emerged in Serbia in the past several years have used this narrative and tied it to the Syrian experience, arguing that two countries have suffered the same fate and that Serbia has been fighting alone long enough. Radical far right movements disguised as humanitarian and human rights organisations helping Serbs in Kosovo have started multiplying, and nationalists from across Europe have started arriving in Serbia to support one of the few strongholds of white European civilisation in resistance against Muslims and Western aggressors. If the EU fails to take a more active role in countering these types of activities and making sure that European integration becomes an attractive option for the Serbian society, the rise of radical movements in the region could present a serious security threat. While the anti-immigration platform in Serbia might not result in a vote swing any time soon, its far more powerful role is the "rebranding" opportunity it offers to the far right, transforming it into a European player and a member of the global network of actors, while allowing it to present itself as a force working to protect its own people and national borders.

\footnotetext{
73 Tepić 2018.

74 Ibid.
} 


\section{References}

Akkerman, Tjitske, and Sarah L. de Lange. 2012. "Radical Right Parties in Office: Incumbency Records and the Electoral Cost of Governing." Government and Opposition 47(4): 574-96.

Akkerman, Tjitske. 2012. "Comparing Radical Right Parties in Government: Immigration and Integration Policies in Nine Countries (1996-2010)." West European Politics 35(3): 511-529.

Anastasijevic, Dejan. 2008. “Organized crime in the Western Balkans." Trends in Organized Crime 11(4): 430-436.

Anu Toots, and Janika Bachmann. 2010. "Contemporary Welfare Regimes in Baltic States: Adapting Post-Communist Conditions to Post-Modern Challenges." Studies of Transition States and Societies 2(2): 31-44.

Arman, Murat Necip. Sarper Ağır Bülent, and Barış Gürsoy. 2016. "European Perspective of Human Security and the Western Balkans". Revista de Stiinte Politice 50: $41-54$.

Art, David. 2011. Inside the Radical Right: The Development of Anti-Immigrant Parties in Western Europe. New York: Cambridge University Press.

Art, David. 2012. "Inside the Radical Right: The Development of Anti-Immigrant Parties in Western Europe." West European Politics 35(5): 1208-9.

Arzheimer, Kai, and Elisabeth Carter. 2006. "Political Opportunity Structures and Right-Wing Extremist Party Success." European Journal of Political Research 45(3): 419-43.

Arzheimer, Kai. 2008. "Protest, Neo-Liberalism or Anti-Immigrant Sentiment: What Motivates the Voters of the Extreme Right in Western Europe?" Zeitschrift Für Vergleichende Politikwissenschaft 2(2):173.

Arzheimer, Kai. 2009. "Contextual Factors and the Extreme Right Vote in Western Europe, 1980-2002.” American Journal of Political Science 53(2): 259-75.

Attinà, Fulvio. 2016. "Migration Drivers, the EU External Migration Policy and Crisis Management." Romanian Journal of European Affairs16 (4): 15-31.

Babić, Marko. 2015. "Defining Political Extremism in the Balkans. The Case of Serbia." Interdisciplinary Political and Cultural Journal 17(1): 73-90. 
Bakić, Jovo. 2009. "Extreme-Right Ideology, Practice and Supporters: Case Study of the Serbian Radical Party.'Journal of Contemporary European Studies 17(2): 193-207.

Bale, Tim, Christoffer, André KrouwelGreen-Pedersen, Kurt Richard Luther, and Nick Sitter. 2010. “If You Can't Beat Them, Join Them? Explaining Social Democratic Responses to the Challenge from the Populist Radical Right in Western Europe." Political Studies 58 (3): 410-26.

Banac, Ivo. 1990. "Political Change and National Diversity” Daedalus 119 (1): 141159.

Banki, Susan. 2006. "Burmese Refugees in Tokyo: Livelihoods in the Urban Environment."Journal of Refugee Studies 19 (3): 328-44.

Bassuener, Kurt W. 2016. "The EU and Member State Building - European Foreign Policy in the Western Balkans." East European Politics 32(4): 568-70.

Belgrade Center for Human Rights. 2016. "Conditions in Reception Facilities. AIDA - Asylum Information Database." Belgrade Center for Human Rights. Accessed November 9, 2017. http://www. asylumineurope. org/reports/country/serbia/ conditions-reception-facilities.

Belgrade Center for Human Rights. 2017. "Pravo na azil u Republici Srbiji 2016." Belgrade Center for Human Rights. Accessed November 9, 2017. http://www. bgcentar. org. rs/bgcentar/wp-content/uploads/2017/03/Pravo-na-azil-u-RepubliciSrbiji-2016-FINAL-za-stampu. pdf.

Berlovac, Bojana. 2011. "Serbian Progressives Link Up With Austrian Far Right."Balkan Insight, June 20. Accessed November 7, 2017. http://www. balkaninsight. com/en/article/serbia-s-progressives-to-launch-pan-european-groupwith-austrian-far-rights.

Betz, Hans-Georg, and Immerfall, Stefan. 1998. The New Politics of the Right: NeoPopulist Parties and Movements in Established Democracies Betz. New York: St. Martin冈s Press.

Betz, Hans-Georg. 1994. Radical Right-Wing Populism in Western Europe. New York: St Martin's Press.

Beutler, Bengt. 2017. "Solidarity in the EU: A Critique of Solidarity and of the EU." In Solidarity in the European Union, edited by Andreas Grimmel and Susanne My Giang, 21-35. Cham: Springer. 
Beznec, B., Marc Speer, and Marta Stojic Mitrović. 2016. "Governing the Balkan Route: Macedonia, Serbia and the European Border Regime." Rosa Luxemburg Stiftung Southeast Europe. Accessed November 9, 2017.http://www. rosalux. rs/sites/ default/files/publications/5\%20Governing\%20the\%20Balkan\%20Route\%20web. pdf.

Bieber, Florian. 2006. "Serbia: Minorities in a Reluctant State." In European Yearbook of Minority Issues 5, edited by European Centre for Minority Issues and The European Academy Bozen/Bolzano, 243-54. Brill:Nijhoff.

Biermann, Rafael. 2014. “Coercive Europeanization: The EU's Struggle to Contain Secessionism in the Balkans." European Security 23 (4): 484-508.

Binder, David. 2008. “The Time of Epithets.” Mediterranean Quarterly 19(4): 81-90.

BIRN. 2017. "Serbian Monarchists, British Right-Wingers Plot Kosovo Resistance." Balkan Insight, 3 November. http://www.balkaninsight.com/en/article/serbianmonarchists-british-right-wingers-plot-kosovo-resistance--11-02-2017.

Biserko, Sonja. 2013. “Extremism: A Follow-up to the Greater Serbia Project.” In Extremism-Recognizing a Social Evil, 9-18. Helsinki Committee for Human Rights in Serbia. Accessed September 18, 2018. https://www.helsinki.org.rs/doc/files34.pdf

Bobic, Mirjana; Babovic, Marija. 2013. "International Migration in Serbia - Facts and Policies." Sociologija 55(2): 209-228.

Bokova, Irina. 2002. "Integrating Southeastern Europe into the European Mainstream."Southeast European and Black Sea Studies 2(1): 23-42.

Bolzoni, Magda, Enrico Gargiulo, and Michele Manocchi. 2015. “The Social Consequences of the Denied Access to Housing for Refugees in Urban Settings: The Case of Turin, Italy." International Journal of Housing Policy 15(4): 400-417.

Boomgaarden, Hajo G., and Rens Vliegenthart. 2007. "Explaining the Rise of AntiImmigrant Parties: The Role of News Media Content." Electoral Studies 26(2): 40417.

Bornschier, Simon. 2010. Cleavage Politics and the Populist Right: The New Cultural Conflict in Western Europe. Temple University Press.

Boswell, Christina. 2011. Migration and Mobility in the European Union. New York: Palgrave Macmillan. 
Brigida, J. Lester Feder, Valeria. 2017. "People Are Watching This Election To See If Fascism Is Making A Comeback In Italy. ” BuzzFeed, September 16. Accessed December 6. https://www. buzzfeed. com/lesterfeder/a-priest-and-a-fascist.

Bronner, Stephen Eric. 1993. “The New Right: Reflections on an International Phenomenon." New Political Science 12(1-2): 87-98.

Brubaker, Rogers, and David D. Laitin. 1998. "Ethnic and Nationalist Violence." Annual Review of Sociology24: 423-52.

Bucken-knapp, Gregg, Jonas Hinnfors, and Andrea Spehar. 2014. "Political Parties and Migration Policy Puzzles: The European Scene." Comparative European Politics 12(6): 557-67.

Buhr, Franz. 2018. "Using the City: Migrant Spatial Integration as Urban Practice."Journal of Ethnic and Migration Studies 44(2): 307-20.

Bustikova, Lenka, and Herbert Kitschelt. 2009. “The Radical Right in PostCommunist Europe. Comparative Perspectives on Legacies and Party Competition." Communist and Post-Communist Studies, Legacies and the Radical Right in post1989 Central and Eastern Europe 42(4): 459-83.

Bustikova, Lenka. 2009. “The Extreme Right in Eastern Europe: EU Accession and the Quality of Governance." Journal of Contemporary European Studies 17(2): 22339.

Cahn, Claude. 2012. "Minorities, Citizenship and Statelessness in Europe Statelessness in Europe." European Journal of Migration and Law 14: 297-316.

Caiani, Manuela, and Elena Pavan. 2017. "Inconvenient Solidarities': Extreme-Right Online Networks and the Construction of a Critical Frame Against Europe." In Solidarity in the European Union, edited by Andreas Grimmel, Susanne My Giang, 145-60. Cham: Springer.

Caiani, Manuela, and Patricia Kröll. 2015. "The Transnationalization of the Extreme Right and the Use of the Internet." International Journal of Comparative and Applied Criminal Justice 39(4): 331-51.

Campbell, Elizabeth H. 2006. "Urban Refugees in Nairobi: Problems of Protection, Mechanisms of Survival, and Possibilities for Integration." Journal of Refugee Studies 19: 396-414. 
Carmichael, Stefanie Castrilli. 2011. “The Enterprise of Integration: The Case of Urban Refugees in Rwanda.” M. A. thesis. Saint Mary’s University (Canada).

Carter, Elisabeth L. 2005. The Extreme Right in Western Europe: Success or Failure? Manchester: New York: Manchester University Press.

Cas Mudde. 2005. "Racist Extremism in Central and Eastern Europe." East European Politics and Societies 19(2): 161-84.

Cingolani, Pietro. 2016. "Turin in Transition: Shifting Boundaries in Two PostIndustrial Neighbourhoods." In Inter-Group Relations and Migrant Integration in European Cities, edited by Ferruccio Pastore, Irene Ponzo, 123-49. Cham: Springer.

Collantes-Celador, Gemma. Juncos, Ana E. 2012. “The EU and border management in the Western Balkans: preparing for European integration or safeguarding EU external borders?" Southeast European and Black Sea Studies 12(2): 201-220.

Colovic, Ivan. 2002. Politics of identity in Serbia: essays in political anthropology. New York University Press.

Commissioner for Human Rights. 2013. "The right to leave a country." Council of Europe. Accessed August 8, 2017. http://www. coe. int/t/commissioner/source/ prems/prems150813_GBR_1700_TheRightToLeaveACountry_web. pdf.

Constitution of the Republic of Serbia. http://www. srbija. gov. rs/cinjenice_o_srbiji/ ustav_odredbe. php?id=218.

Cristiano, Ricardo. 2017. "What Are CasaPound and the European Front for Syria up To?” We Write What We Like (blog), October 31. Accessed December 4, 2017. https://wewritewhatwelike. com/2017/10/31/what-are-casapound-and-theeuropean-front-for-syria-up-to/.

Csergo, Zsuzsa, and James M. Goldgeier. 2004. "Nationalist Strategies and European Integration." Perspectives on Politics 2(1): 21-37.

Dangerfield, Martin. 2004. "Regional cooperation in the Western Balkans: Stabilisation device or integration policy?" Perspectives on European Politics and Society. 5(2): 203-241.

Darrell Jackson. 2011. "Europe and the Migrant Experience: Transforming Integration."Transformation 28(1): 14-28. 
Davidson, Neil, and Richard Saull. 2017. "Neoliberalism and the Far-Right: A Contradictory Embrace." Critical Sociology 43(4-5): 707-24.

Despot, Andrea, Hannes Grandits, Wolfgang Höpken, Dusan Reljic, Gabriella Schubert, and Sevasti Trubeta. 2016. "Beyond the 'Balkan Route'or Why Southeastern Europe Remains a Core Issue for Europe." SüdostEuropa 64(3): 381-95.

Dizikes, Peter. 2010. "Understanding Anti-Immigrant Sentiment." MIT News, February 19. Accessed December 4, 2017. http://news. mit. edu/2010/antiimmigrant-sentiment-0219.

Djokić, Dejan. 2012. "Nationalism, Myth and Reinterpretation of History: The Neglected Case of Interwar Yugoslavia." European History Quarterly 42(1): 71-95.

Dollard, John. 1939. Frustration and Aggression. New Haven, CT: Yale University Press.

Downs, William M. 2012. Political Extremism in Democracies: Combating Intolerance. New York: Palgrave Macmillan.

Dragović-Soso, Jasna. 2004. "Rethinking Yugoslavia: Serbian Intellectuals and the 'National Question' in Historical Perspective." Contemporary European History 13(2): $170-84$.

Dugin, Aleksandr. 2012. The Fourth Political Theory. London: Arktos.

Dugin, Aleksandr. 2014. Eurasian Mission: An Introduction to Neo-Eurasianism. London: ARKTOS.

Dugin, Aleksandr. 2014. Putin vs Putin: Vladimir Putin Viewed from the Right. London: Arktos

Dzombic, Jelena. 2014. "Rightwing Extremism in Serbia."Race E Class 55(4): 106110.

Eatwell, Roger, and Cas Mudde. 2004. Western Democracies and the New Extreme Right Challenge. New York: Routledge.

Eriksen, Erik O. 2017. "Structural Injustice: The Eurozone Crisis and the Duty of Solidarity." In Solidarity in the European Union, edited by Andreas Grimmel, Susanne My Giang, 97-118. Cham: Springer. 
European Asylum Support Office. 2015. "Asylum Applicants from the Western Balkans: comparative analysis of trends, push-pull factors and responses - Update." European Asylum Support Office. Accessed September 18, 2018. https://www. easo. europa. eu/sites/default/files/public/Asylum-Applicants-from-the-Western-Balkans_ Update_r. pdf.

European Commission. 2013. "Serbia 2013 Progress Report. Enlargement Strategy and Main Challenges 2013-2014. "European Commission, October 16. Accessed September 3, 2017. https://ec. europa. eu/neighbourhood-enlargement/sites/near/ files/pdf/key_documents/2013/package/sr_rapport_2013.pdf.

European Commission. 2014. "Chapter 24 - Justice, freedom and security." European Commission, May 15. Accessed August 8, 2017. https://ec. europa. eu/ neighbourhood-enlargement/sites/near/files/pdf/key_documents/2014/140729screening-report-chapter-24-serbia. pdf.

European Commission. 2016. "Implementing the EU-Turkey Statement - Questions and Answers." European Commission, December 8. Accessed September 5, 2017. http://europa.eu/rapid/press-release_MEMO-16-4321_en.htm

European Commission. 2017. "EU announces additional emergency aid to help refugees in Serbia." European Commission, October 8. Accessed August 8, 2017. https://reliefweb. int/report/serbia/eu-announces-additional-emergency-aid-helprefugees-serbia.

European Commission. 2017. "European Civil Protection and Humanitarian Aid Operations." European Commission, July 20. Accessed August 8, 2018. http://ec. europa. eu/echo/files/aid/countries/factsheets/serbia_en. pdf.

European Union Institute for Security Studies. 2003. “The Southern Balkans Perspectives from the Region." European Union Institute for Security Studies, April 4. Accessed September 4, 2017. https://publications. europa. eu/en/publicationdetail/-/publication/13569138-b7b5-4404-afa8-b6f36c7380b4/language-en.

Fatić, Aleksandar. 2010. "A Strategy Based on Doubt: Russia Courts Southeast Europe." Contemporary Security Policy 31(3): 441-64.

Fauser, Margit. 2012. Migrants and Cities: The Accommodation of Migrant Organizations in Europe. Farnham: Ashgate.

Fekete, Liz. 2005. “The Deportation Machine: Europe, Asylum and Human Rights."Race E Class 47(1): 64-78. 
Ferran Requejo Coll, Nagel Klaus-Jürgen, eds. 2015. Politics of Religion and Nationalism: Federalism, Consociationalism and Seccession. New York: Routledge, Taylor \& Francis Group.

Ferruh Yilmaz. 2012. "Right-Wing Hegemony and Immigration: How the Populist Far-Right Achieved Hegemony through the Immigration Debate in Europe." Current Sociology 60(3): 368-81.

Fiddian-Qasmiyeh, Elena, Gil Loescher, Katy Long, Nando Sigona, and Loren B. Landau. 2014. Urban Refugees and IDPs. Oxford University Press.

Frelak, Justyna Segeš. 217. "Solidarity in European Migration Policy: The Perspective of the Visegrád States." In Solidarity in the European Union, edited by Andreas Grimmel, Susanne My Giang, 81-95. Cham: Springer.

Galeotti, Mark. 2018. “Do the Western Balkans face a coming Russian Storm?” European Council on Foreign Relations, April 4. Accessed June 1, 2018. https://www. ecfr.eu/publications/summary/do_the_western_balkans_face_a_coming_russian_ storm

Galtung, Johan. 1994. “The Emerging European Supernationalism.” International Journal of Sociology 24(2-3): 148-65.

Geddes, Andrew. 2003. The Politics of Migration and Immigration in Europe. Calif.: SAGE Publications.

Geddes, Andrew. 2008. Immigration and European Integration. Towards Fortress Europe. Manchester: Manchester University Press.

Geertje Lucassen, and Marcel Lubbers. 2012. "Who Fears What? Explaining Far-Right-Wing Preference in Europe by Distinguishing Perceived Cultural and Economic Ethnic Threats." Comparative Political Studies 45(5): 547-74.

Golder, Matt. 2016. "Far Right Parties in Europe." Annual Review of Political Science 19(1): 477-97.

Goodwin, Matthew. 2011. "Right Response.Understanding and Countering Populist Extremism in Europe." Chatham House, September 1. Accessed June 3, 2011. https:// www.chathamhouse.org/publications/papers/view/178301

Graauw, Els de, and Floris Vermeulen. 2016. "Cities and the Politics of Immigrant Integration: A Comparison of Berlin, Amsterdam, New York City, and San Francisco." Journal of Ethnic and Migration Studies 42(6): 989-1012. 
Grabska, Katarzyna. 2006. "Marginalization in Urban Spaces of the Global South: Urban Refugees in Cairo." Journal of Refugee Studies 19: 287-307.

Grimmel, Andreas, and Susanne My Giang. 2017. "Introduction: Solidarity Lost? The European Union and the Crisis of One of Its Core Values. " In Solidarity in the European Union, edited by Andreas Grimmel, Susanne My Giang, 1-6. Cham: Springer.

Grimmel, Andreas. 2017. "Solidarity in the European Union: Fundamental Value or 'Empty Signifier." In Solidarity in the European Union, edited by AndreasGrimmel, Susanne My Giang, 161-75. Cham: Springer.

Grosaru, Florin Eduard. 2012. "The Strategic Importance and the Actors of SouthEastern Europe."Journal of Defense Resources Management3(1): 101-12.

Grupa 484. 2016. "We and the Others. Statement on the Occasion of the World Refugee Day”. Grupa 484. Accessed August 8, 2017. http://grupa484. org. rs/en/ statement-on-the-occasion-of-the-world-refugee-day/.

Gyárfášová, O., and G. Mesežnikov. 2015. Actors, Agenda, and Appeal of the Radical Nationalist Right in Slovakia. Oxon - New York: Routledge.

Hainsworth, Paul. 2000. The Politics of the Extreme Right. From the Margins to the Mainstream. NewYork: Pinter.

Hainsworth, Paul. 2008. The Extreme Right in Western Europe. Making of the Contemporary World. New York: Routledge.

Hampshire, James. 2015. “Europe’s Migration Crisis.” Political Insight 6(3): 8-11.

Huysmans, Jef. 2000. "The European Union and the Securitization of Migration." Journal of Common Market Studies 38(5): 751-777.

Huysmans, Jef. 2006. The Politics of Insecurity: Fear, Migration, and Asylum in the EU. New York: Routledge.

Ignazi, Piero. 2003. Extreme Right Parties in Western Europe. New York: Oxford University Press.

Ireland, Patrick R. 2017. Migrant Integration in Times of Economic Crisis: Policy Responses from European and North American Global Cities. Cham: Springer. 
Ishiyama, John. 2009. "Historical Legacies and the Size of the Red-Brown Vote in Post-Communist Politics." Communist and Post-Communist Studies, Legacies and the Radical Right in post-1989 Central and Eastern Europe 42(4): 485-504.

Jackson, Darell. 2011. "Europe and the Migrant Experience: Transforming Integration." Transformation 28(1): 14-28.

Jacobsen, Karen. 2006. "Refugees and Asylum Seekers in Urban Areas: A Livelihood Perspective Editorial Introduction.” Journal of Refugee Studies 19: 273-86.

Jensen, Ole, and Ben Gidley. 2016. “They've Got Their Wine Bars, We've Got Our Pubs': Housing, Diversity and Community in Two South London Neighbourhoods." In Inter-Group Relations and Migrant Integration in European Cities, 19-38.

Kai, Arzheimer. 2008. "Protest, Neo-Liberalism or Anti-Immigrant Sentiment: What Motivates the Voters of the Extreme Right in Western Europe?" Zeitschrift Für Vergleichende Politikwissenschaft 2(2): 173.

Katzenstein, Peter J., and Timothy A. Byrnes. 2006. “Transnational Religion in an Expanding Europe." Perspectives on Politics 4(4): 679-94.

Kearns, Ade, Elise Whitley, Matt Egan, Catherine Tabbner, and Carol Tannahill. 2017. "Healthy Migrants in an Unhealthy City? The Effects of Time on the Health of Migrants Living in Deprived Areas of Glasgow. "Journal of International Migration and Integration 18(3): 675-98.

Kedar, Orit. 2005. "When Moderate Voters Prefer Extreme Parties: Policy Balancing in Parliamentary Elections.” The American Political Science Review 99(2): 185-99.

Keil, Soeren. 2013. "Europeanization, State-Building and Democratization in the Western Balkans." Nationalities Papers 41(3): 343-53.

Keil, Soeren. Arkan, Zeynep. 2016. “The EU and Member State Building - European Foreign Policy in the Western Balkans." East European Politics 32(4): 568-70.

Kilibarda, Pavle, and Nikola Kovacevic. 2016. "Country Report: Serbia." The Asylum Information Database (AIDA). Accessed August 8, 2017. http://www. ecre. org/wpcontent/uploads/2016/06/aida_sr. pdf.

Kinnvall, Catarina, and Paul Nesbitt-Larking. 2013. "Securitising Citizenship:

Ordering Practices and Strategies of Resistance." Global Society 27(3): 337-59. 
Kinnvall, Catarina. 2015. "Borders and Fear: Insecurity, Gender and the Far Right in Europe." Journal of Contemporary European Studies 23(4): 514-29.

Kitschelt, Herbert, and Anthony J. McGann. 1995. The Radical Right in Western Europe: A Comparative Analysis. Ann Arbor: University of Michigan Press.

Kitschelt, Herbert. 2007. "Growth and Persistence of the Radical Right in Postindustrial Democracies: Advances and Challenges in Comparative Research." West European Politics 30(5): 1176-1206.

Knodt, Michèle, and Anne Tews. 2017. "European Solidarity and Its Limits: Insights from Current Political Challenges." In Solidarity in the European Union, edited by AndreasGrimmel, Susanne My Giang, 47-64. Cham: Springer.

Kogovsek Salamon, Neza. 2016. "Asylum Systems in the Western Balkan Countries: Current Issues." International Migration 54(6): 151-163.

Köhler, Claudia. 2016. "Rise and Resolution of Ethnic Conflicts in Nuremberg Neighbourhoods." In Inter-Group Relations and Migrant Integration in European Cities, 39-67.

Koizumi, Koichi, and Gerhard Hoffstaedter. 2015. Urban Refugees: Challenges in Protection, Services and Policy. New York: Routledge.

Kolstø, Pal, and Helge Blakkisrud. 2016. The New Russian Nationalism. Edinburgh University Press.

Kotzur, Markus. 2017. "Solidarity as a Legal Concept." In Solidarity in the European Union, edited by AndreasGrimmel, Susanne My Giang, 37-45. Cham: Springer.

Krastev, Ivan. 1999. "Human Security in South-East Europe." UNDP Special Report. Accessed June 2017. http://web. ceu. hu/cps/bluebird/eve/statebuilding/krastev_ humansecurity. pdf.

Laruelle, Marlène ed. 2015. Eurasianism and the European Far Right: Reshaping the Europe-Russia Relationship. London: Lexington Books.

Laruelle, Marlene. 2008. Russian Eurasianism: An Ideology of Empire. Baltimore: Johns Hopkins University Press.

Laruelle, Marlene. 2010. “The Ideological Shift on the Russian Radical Right: From Demonizing the West to Fear of Migrants." Problems of Post-Communism 57(6): 19-31. 
Laruelle, Marlene. 2015. Eurasianism and the European Far Right: Reshaping the Europe-Russia Relationship. Lexington Books.

Laryš, Martin, and Miroslav Mareš. 2011. "Right-Wing Extremist Violence in the Russian Federation." Europe-Asia Studies 63(1): 129-54.

Lazaridis, Gabriella, and Dimitris Skleparis. 2016. "Securitization of Migration and the Far Right: The Case of Greek Security Professionals." International Migration 54(2): 176-92.

Lazaridis, Gabriella, and Mariangela Veikou. 2017. “The Rise of the Far Right in Greece and Opposition to 'Othering', Hate Speech, and Crime by Civil and Civic Organizations.” Journal of Civil Society 13(1): 1-17.

Lazaridis, Gabriella, Giovanna Campani, and Annie Benveniste, eds. 2016. The Rise of the Far Right in Europe. London: Palgrave Macmillan UK.

Lazaridis, Gabriella. Veikou, Mariangela. 2017. “The Rise of the Far Right in Greece and Opposition to 'Othering', Hate Speech, and Crime by Civil and Civic Organizations.” Journal of Civil Society 13(1): 1-17.

Lenka Bustikova. 2014. "Revenge of the Radical Right." Comparative Political Studies 47(12): 1738-65.

Livanios, Dimitris. 2002. "Nationalism in Eastern Europe and the Balkans." Southeast European and Black Sea Studies 2(2): 165-76.

Lubbers, Marcel, and Marcel Coenders. 2017. "Nationalistic Attitudes and Voting for the Radical Right in Europe." European Union Politics 18(1): 98-118.

Lucassen, Geertje, and Marcel Lubbers. 2012. "Who Fears What? Explaining Far-Right-Wing Preference in Europe by Distinguishing Perceived Cultural and Economic Ethnic Threats." Comparative Political Studies 45(5): 547-74.

Lukic, Vesna. 2016. "Understanding Transit Asylum Migration: Evidence from Serbia." International Migration 54(4): 31-43.

Lyytinen, Eveliina. 2015. "Refugees' Conceptualizations of 'Protection Space': Geographical Scales of Urban Protection and Host-Refugee Relations." Refugee Survey Quarterly 34(2): 45-77. 
Mammone, Andrea, Emmanuel Godin, and Brian Jenkins. 2009. "Introduction: The Extreme Right in Contemporary Europe: History, Interpretation, Performance” Journal of Contemporary European Studies 17(2): 147-49.

Manners, Ian. 2013. "European Security Union: Bordering and Governing a Secure Europe in a Better World?” Global Society 27(3): 398-416.

Mareš, Miroslav. 2011. "Czech Extreme Right Parties an Unsuccessful Story." Communist and Post-Communist Studies 44(4): 283-98.

Marusi, Damir, Sarah Bedenbaugh, and Damon Wilson. 2017. "Balkans Forward: A New US Strategy for the Region." Atlantic Council. Accessed September 18, 2018. http://www.atlanticcouncil.org/images/Balkans_Forward_web_1128.pdf

Matejskova, Tatiana, and Helga Leitner. 2011. "Urban Encounters with Difference: The Contact Hypothesis and Immigrant Integration Projects in Eastern Berlin."Social E Cultural Geography 12(7): 717-41.

Mats, Deland, Michael Minkenberg, and Christin Mays, eds. 2014. In the Tracks of Breivik: Far Right Networks in Northern and Eastern Europe. Wien: Lit Verlag.

Mayer, Nonna. 2013. "From Jean-Marie to Marine Le Pen: Electoral Change on the Far Right." Parliamentary Affairs 66(1): 160-78.

McLaren, Lauren M. 2012. “The Cultural Divide in Europe: Migration, Multiculturalism, and Political Trust.” World Politics 64(2): 199-241.

Mierina, Inta, and Ilze Korol̦eva. 2015. "Support for Far Right Ideology and AntiMigrant Attitudes among Youth in Europe: A Comparative Analysis.” The Sociological Review 63(2): 183-205.

Milosavljevic, Boris. 2002. "Relations between the State and Religious Communities in the Federal Republic of Yugoslavia." Brigham Young University Law Review 2002(2): 311-340.

Minkenberg, Michael ed. 2015. Transforming the Transformation?: The East European Radical Right in the Political Process. New York: Routledge.

Minkenberg, Michael. 2000. “The Renewal of the Radical Right: Between Modernity and Anti-Modernity." Government and Opposition 35(2): 170-88. 
Minkenberg, Michael. 2015. Transforming the Transformation?: The East European Radical Right in the Political Process. New York: Routledge.

Minkenberg, Michael. 2017. The Radical Right in Eastern Europe: Democracy under Siege? New York: Palgrave Macmillan.

Mudde, Cas. 2000. The Ideology of the Extreme Right. New York: Manchester University Press.

Mudde, Cas. 2007. Populist Radical Right Parties in Europe. New York: Cambridge University Press.

Mudde, Cas. 2014. Youth and the Extreme Right. New York: International Debate Education Association.

Mullins, David, and Pat Jones. 2009. "Refugee Integration and Access to Housing: A Network Management Perspective." Journal of Housing $\mathcal{E}$ the Built Environment 24(2): 103-25.

Neal, Andrew W. 2009. "Securitization and Risk at the EU Border: The Origins of FRONTEX". Journal of Common Market Studies 47(2): 333-56.

Norris, Pippa. 2005. Radical Right: Voters and Parties in the Electoral Market. New York, NY: Cambridge University Press.

Odmalm, Pontus. 2011. "Political Parties and 'the Immigration Issue': Issue Ownership in Swedish Parliamentary Elections 1991-2010." West European Politics 34(5): 1070-91.

Oliver, Tim. 2017. "The EU Falling Apart? Theoretical Discussions of Brexit, Grexit and Other Exit Scenarios." In Solidarity in the European Union, edited by AndreasGrimmel, Susanne My Giang, 131-44. Cham: Springer.

Olzak, Susan. 1987. "Causes of Ethnic Conflict and Protest in Urban America, 18771889." Social Science Research 16(2): 185-210.

Organization for Security and Co-Operation in Europe Mission to Serbia. 2008. "Refugees and displaced persons - state of affairs." Organization for Security and CoOperation in Europe Mission to Serbia. Accessed August 8, 2017. http://www. osce. org/serbia/24323?download=true.

Pankowski, Rafał. 2010. The Populist Radical Right in Poland: The Patriots. New York: Routledge. 
Passey, Megan. 2017. "Life in limbo. The consequences of thwarted mobility for refugees, asylum seekers and other migrants in Serbia." Mixed Migration Platform. Accessed September 10, 2017. http://mixedmigrationplatform. org/wp-content/ uploads/2017/10/Life-in-Limbo_19102017. pdf.

Pastore, Ferruccio, and Irene Ponzo. 2016. "Boundaries, Barriers and Bridges: Comparative Findings from European Neighbourhoods." In Inter-Group Relations and Migrant Integration in European Cities, edited by Ferruccio Pastore, Irene Ponzo, 177-201. Cham: Springer.

Pastore, Ferruccio. 2016. "Introduction." In Inter-Group Relations and Migrant Integration in European Cities, edited by Ferruccio Pastore, Irene Ponzo, 1-18. Cham: Springer.

Pásztor, Péter, and Adam Michnik. 2015. “The Miseries of East European Small States." In The Art of Peacemaking, edited by István Bibó, 130-80. New Haven: Yale University Press.

Pavasovic Trost, Tamara. 2012. "Dealing with the Past: History and Identity in Serbia and Croatia." Ph. D. diss., Harvard University.

Pogliano, Andrea. 2016. "News Media and Immigration in the EU: Where and How the Local Dimension Matters." In Inter-Group Relations and Migrant Integration in European Cities, edited by Ferruccio Pastore, Irene Ponzo, 151-76. Cham: Springer.

Pop-Eleches, Grigore. 2010. "Throwing out the Bums: Protest Voting and Unorthodox Parties after Communism.” World Politics 62(2): 221-60.

Praxis. 2017. "Praxis Protection Monitoring Report on Migration - September 2017." Praxis. Accessed October 7, 2017. http://praxis. org. rs/images/praxis_downloads/ Praxis_Protection_Monitoring_Report_September_2017.pdf.

Pupovac, David. 2015. The Radical Right in Policy Space: A Comparative Analysis of Radical Right Parties in Eastern and Western Europe. Central European University.

Ramet, Sabrina P. 1999. The Radical Right in Central and Eastern Europe since 1989. PA: Pennsylvania State University Press.

Roudometof, Victor. 1996. "The Consolidation of National Minorities in Southeastern Europe." Journal of Political and Military Sociology 24(2):189-207.

Rudic, F. 2017. “Serbia Struggles to Process Refugees' Asylum Claims.” Balkan Insight, August 10. Accessed November 9. http://www. balkaninsight. com/en/ article/serbia-slow-to-process-refugees-asylum-requests-08-09-2017. 
Rydgren, Jens. 2005. "Is Extreme Right-Wing Populism Contagious? Explaining the Emergence of a New Party Family." European Journal of Political Research 44(3): 413-37.

Rydgren, Jens. 2008. "Immigration Sceptics, Xenophobes or Racists? Radical RightWing Voting in Six West European Countries." European Journal of Political Research 47(6): 737-65.

Rydgren, Jens. 2013. Class Politics and the Radical Right. New York: Routledge.

Rygiel, Kim. Baban, Feyzi. Ilcan, Suzan. 2016. “The Syrian refugee crisis: The EUTurkey 'deal' and temporary protection." Global Social Policy16(3): 315-320.

Sandercock, Leonie, Giovanni Attili, Val Cavers, and Paula Carr. 2009. Where Strangers Become Neighbours: Integrating Immigrants in Vancouver, Canada. New York: Springer.

Schain, Martin, Aristide R. Zolberg, and Patrick Hossay. 2002. Shadows over Europe: The Development and Impact of the Extreme Right in Western Europe. New York: Palgrave MacMillan.

Serbia: Law of 2007 on Asylum. National Legislative Bodies, November 26. Accessed June 3, 2017. http://www. refworld. org/docid/47b46e2f9. html.

Serbia: Law of 2008 on Foreigners. 2008. National Legislative Bodies, October 23. Accessed June 3, 2017.http://www. refworld. org/docid/4b5d715a2. html.

Serbia: Law on Migration Management.National Legislative Bodies, October 23. Accessed June 3, 2017. http://www. kirs. gov. rs/docs/Zakon_o_upravljanju_ migracijama. pdf.

Simić, Andrei. 2016. "Idealization of the West and Cultural Dissonance in Serbia." Anthropology Now 8(2): 104-114.

Sirkeci, Ibrahim, Jeffrey H. Cohen and Dili Ratha. 2012. "Migration and Remittances during the Global Financial Crisis and Beyond." World Bank. Accessed August 3, 2017. http://documents.worldbank.org/curated/en/701621468149081927/Migrationand-remittances-during-the-global-financial-crisis-and-beyond.

Sommers, Marc. 2001. "Young, Male and Pentecostal: Urban Refugees in Dar Es Salaam, Tanzania.”Journal of Refugee Studies 14: 347-70.

Spiegel, Paul. 2010. "Urban Refugee Health: Meeting the Challenges." Forced Migration Review 34: 22-23. 
Stefanovic, Djordje. 2008. "The Path to Weimar Serbia? Explaining the Resurgence of the Serbian Far Right after the Fall of Milosevic." Ethnic and Racial Studies 31(7): 1195-1221.

Steinvorth, Ulrich. 2017. "Applying the Idea of Solidarity to Europe." In Solidarity in the European Union, edited by Andreas Grimmel, Susanne My Giang, 9-19. Cham: Springer.

Stojanovic, M. 2017. "Palma, Dveri i Dodik Uz Kontroverznog Hofera." Dnevni list Danas, September 3. Accessed December 6. http://www. danas. rs/politika. 56. html?news_id=333687\&title $=$ Palma\%2c + Dveri $+\mathrm{i}+$ Dodik + uz + kontroverznog + Hofe ra.

Stojarová, Věra. 2013. The Far Right in the Balkans. Manchester University Press.

Stojic Mitrovic, M. 2016. "Serbian Migration Policy Concerning Irregular Migration and Asylum in the Context of the EU Integration Process." Issues in Ethnology and Anthropology 9(4): 1105-20.

Stojić Mitrović, Marta. 2016. "Presenting as a Problem, Acting as an Opportunity: Four Cases of Socio-Political Conflicts Taking the Presence of Migrants as a Focal Object in Serbia." Glasnik Etnografskog Instituta SANU 62(1): 67-83

Stojić Mitrović, Marta. 2016. “Serbian migration policy concerning irregular migration and asylum in the context of the EU integration process." Issues in Ethnology and Anthropology 9(4): 1105.

Stojić-Mitrović, Marta. 2016. "Serbian Migration Policy Concerning Irregular Migration and Asylum in the Context of the EU Integration Process."

Etnoantropološki Problemi 9(4): 1105-20.

Sum, Paul E. 2010. “The Radical Right in Romania: Political Party Evolution and the Distancing of Romania from Europe." Communist and Post-Communist Studies43(1): 19-29.

Szalai, Boglárka, and Krisztina La-Torre. 2016. "Comfortably Invisible: The Life of Chinese Migrants Around 'The Four Tigers Market' in Budapest.” In Inter-Group Relations and Migrant Integration in European Cities, 69-87. Cham: Springer.

Tamminen, Tanja. 2004. "Cross-border Cooperation in the Southern Balkans: Local, National or European Identity Politics?" Southeast European and Black Sea Studies 4(3): 399-418. 
Tesanović, Tesa. 2014. "Interview with Socialist Leader James Porrazzo". Centre for Syncretic Studies, 29 August. https://syncreticstudies.com/2014/08/29/interviewwith-socialist-leader-james-porrazzo/.

Thorleifsson, Catherine. 2017. "Disposable Strangers: Far-Right Securitisation of Forced Migration in Hungary." Social Anthropology 25(3): 318-34.

Time. 2017. 10-Year-Old Boy Earns 'Little Picasso’ Nickname In Refugee Camp. Time, March 13. Accessed November 9. http://time. com/4699755/little-picassoserbia/.

Tomić, Đorđe. 2013. “On the 'Right' Side? The Radical Right in the Post-Yugoslav Area and the Serbian Case." Fascism 2(1): 94-114

Torbakov, Igor. 2015. "A Parting of Ways? The Kremlin Leadership and Russia's NewGeneration Nationalist Thinkers." Demokratizatsiya 23(4):427.

Torrisi, Steven A. 2000. "Back to the Future: How Serbia Is Heading the Way of Postversailles Germany." European Security 9(4): 111-63.

Trauner, Florian, and Emanuele Manihrassi. 2014. "When Visa-Free Travel Becomes Difficult to Achieve and Easy to Lose: The EU Visa Free Dialogues after the EU's Experience with the Western Balkans." European Journal of Migration and Law 16(1): 125-145.

Trauner, Florian. 2009. "From Membership Conditionality to Policy Conditionality: EU External Governance in South Eastern Europe." Journal of European Public Policy 16(5): 774-90.

Trauner, Florian. 2009. "From membership conditionality to policy conditionality: EU external governance in South Eastern Europe." Journal of European Public Policy 16(5): 774-790.

Trauner, Florian. 2009. "When Visa-free Travel Becomes Difficult to Achieve and Easy to Lose: The EU Visa Free Dialogues after the EU's Experience with the Western Balkans." European Journal of Migration and Law16(1): 125-145.

Tunnard, Christopher R. 2010. "Defeating Milošević: The Role of Networked Organizations and the Internet in Serbia in the 1990s." Ph. D. diss. Fletcher School of Law and Diplomacy, Tufts University.

Tunnard, Christopher. 2003. “From State-Controlled Media to the 'Anarchy' of the Internet: The Changing Influence of Communications and Information in Serbia in the 1990s." Southeast European and Black Sea Studies 3(2): 97-120. 
Umland, Andreas. 2015. "Challenges and Promises of Comparative Research into Post-Soviet Fascism: Methodological and Conceptual Issues in the Study of the Contemporary East European Extreme Right." Communist and Post-Communist Studies 48(2): 169-81.

Umland, Andreas. 2017. "Post-Soviet Neo-Eurasianism, the Putin System, and the Contemporary European Extreme Right.” Perspectives on Politics 15(2): 465-76.

UN High Commissioner for Refugees, UN Country Team in Serbia. 2017. "Serbia Inter-Agency Operational Update March 2017." UNHCR, March 31. Accessed August 3, 2017. http://reliefweb. int/report/serbia/serbia-inter-agency-operationalupdate-march-2017.

UNHCR Refugees Operational Data Portal. 2017. "UNHCR Serbia Update: 18-24 Sep 2017." UNHCR. Accessed July 24, 2017. https://data2. unhcr. org/en/documents/ download/60054.

UNHCR Serbia. 2017. “Europe Refugee Situation: Serbia 2016 in Numbers." UNHCR, February 2017. Accessed June 4, 2017.https://data2. unhcr. org/en/documents/ download/55029.

UNICEF. 2017. "Backpacks and school supplies distributed to Jovan Ristic primary school pupils, including refugee and migrant children." Reliefweb, September 4. Accessed October 3, 2017. https://reliefweb. int/report/serbia/backpacks-andschool-supplies-distributed-jovan-ristic-primary-school-pupils-including.

United States Department of State. 2017. “Serbia 2017 Human Rights Report.” United States Department of State. Accessed September 4, 2017. https://www. state. gov/ documents/organization/277459. pdf.

Valenta, Marko, Drago Zuparic-Iljic, and Tea Vidovic. 2015. "The Reluctant AsylumSeekers: Migrants at the Southeastern Frontiers of the European Migration System." Refugee Survey Quarterly 34(3): 95-113.

Valenta, Marko. Vidovic, Tea. 2015. "The Reluctant Asylum-Seekers: Migrants at the Southeastern Frontiers of the European Migration System: Figure 1." Refugee Survey Quarterly 34(3): 95-113.

Vieten, Ulrike M., and Scott Poynting. 2016. "Contemporary Far-Right Racist Populism in Europe." Journal of Intercultural Studies 37(6): 533-40.

Vigneswaran, Darshan, and Joel Quirk. 2013. "Quantitative Methodological Dilemmas in Urban Refugee Research: A Case Study of Johannesburg." Journal of Refugee Studies 26(1): 110-16. 
Virchow, Fabian. 2016. "PEGIDA: Understanding the Emergence and Essence of Nativist Protest in Dresden." Journal of Intercultural Studies 37(6): 541-55.

Vujacic, Veljko Marko. 1995. "Communism and Nationalism in Russia and Serbia." Ph. D. diss., University of California, Berkeley.

Waele, Henri de. 2017. "Disintegration from Within: Independence and Separatist Movements, the EU Response and the Role of Solidarity." In Solidarity in the European Union, edited by AndreasGrimmel, Susanne My Giang, 119-29. Cham: Springer.

Wenden, Catherine Wihtol de. 2017. "Actual Patterns of Migration Flows: The Challenge of Migration and Asylum in Contemporary Europe." In Solidarity in the European Union, edited by Andreas Grimmel, Susanne My Giang, 67-79. Cham: Springer.

White, James. 2015. "Orthodox Christianity and Nationalism in Nineteenth-Century Southeastern Europe." Europe-Asia Studies 67(6): 992-93.

Wouter van der Brug. 2015. The Politicisation of Migration. New York: Routledge.

Yabanci, Bilge. 2015. “The Far Right in the Balkans.” Europe-Asia Studies 67(5): 84042. 